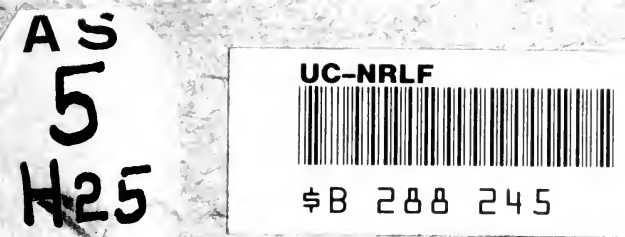




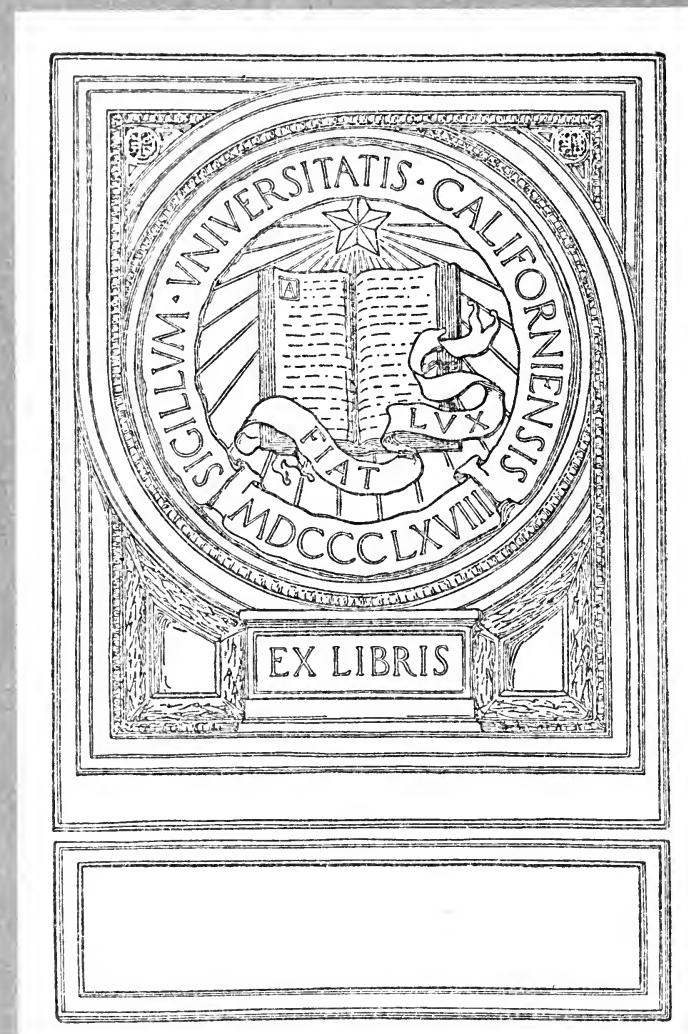




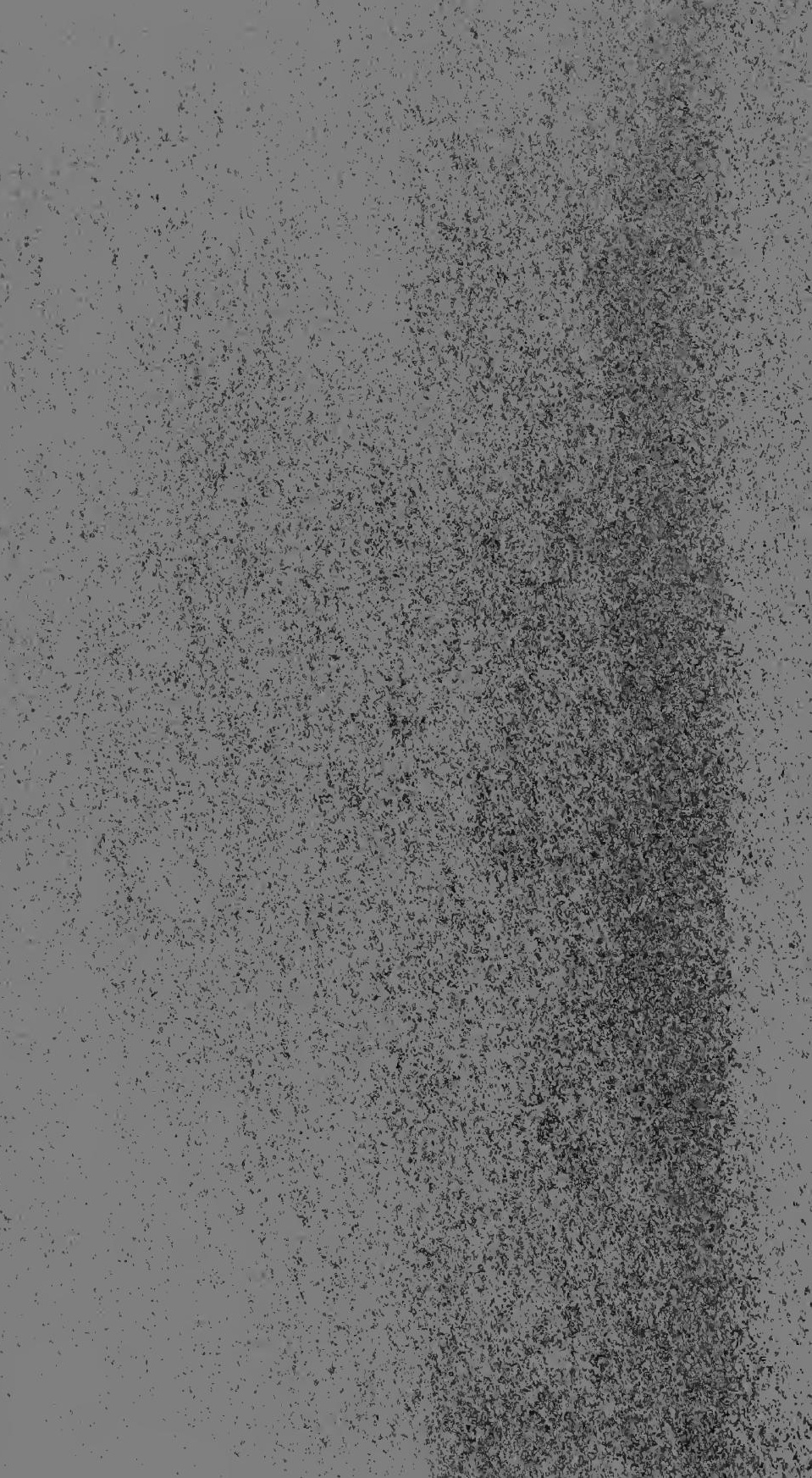




\section{NATIONAL ACADEMIES AND THE} PROGRESS OF RESEARCH

BY

GEORGE ELLERY HALE 


\section{Digitized by the Internet Archive in 2007 with funding from Microsoft Corporation}





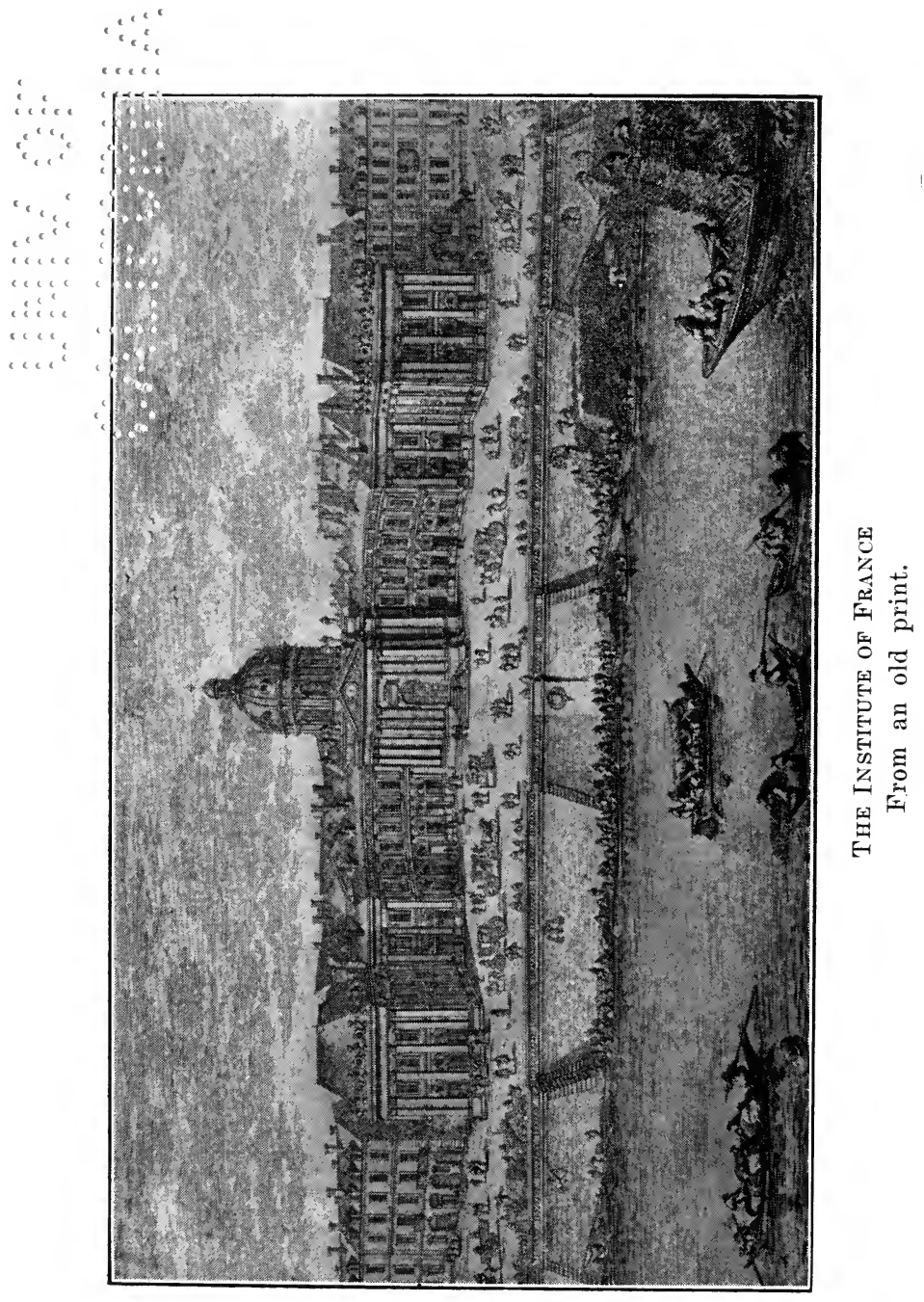




\title{
NATIONAL ACADEMIES AND THE PROGRESS OF RESEARCH
}

\author{
BY \\ GEORGE ELLERY HALE \\ Foreign Secretary of the National Academy of Sciences
}

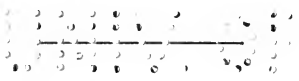

Reprinted from ScIence, Vol. XXXVIII., No. 985, Pages 681-698, November 14, 1913; Vol. XXXIX, No. 997, Pages 189-200, February 6, 1914; Vol. XL., No. 1043, Pages 907-919, December 25, 1914; Vol. XLI., No. 1044, Pages 12-22, January 1, 1915. 


\section{aIf}

\section{THE NEW ERA PRINTING COMPANY LANCASTER, PA.}

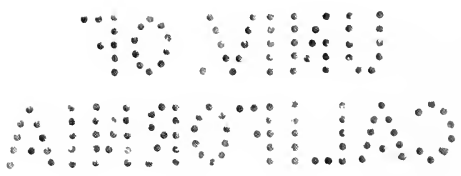




\section{THE WORK OF EUROPEAN ACADEMIES}

THE Academy of Plato, who bequeathed to his followers the walled garden and appointments in the place named after the hero Hekademus, was at once a school of instruction and a society for the development of new knowledge. Here he discussed his philosophy with associates and students while it was still in the making, thus bringing them under the stimulating influence of fresh thought, developing and expanding from day to day. Writing of the Old Academy, which included the schools of Plato and his immediate successors, Cicero remarks :

From their writings and systems all liberal learning, all history, all elegance of language, may be derived; and also, so great is the variety of arts of which they were masters, that no one can come properly armed for any business of importance and credit without being tolerably versed in their writings. . . . It is from this Academy, as from a regular magazine of all the arts, that mathema- 
ticians, poets, musicians, aye, and physicians too, have proceeded.1

The Old Academy was thus the predecessor of our modern academies of science and of our universities as well. Its worldwide influence, while of course primarily due to the brilliant thinkers of the day, may certainly be ascribed in part to the fact that its instruction was given in an atmosphere charged with the stimulus of original thought and constantly broadening ideas. The great success of the German universities, and the outflow from them of the spirit of research into every phase of German life and thought, is undoubtedly due in the largest measure to the application of this principle. Fortunately for the intellectual advancement of the United States, the recognition of its importance has already permeated most of our advanced schools, and is rapidly gaining acceptance in the minds of their governing boards of trustees.

Aristotle, called by Plato "the mind of my school," came from a family of physicians, and thus inherited a taste for experi-

1 Cicero, "De Finibus," Book 5, Yonge's trans. 
mental knowledge. To him we owe the beginnings of exact science and the organization of research on a large scale. Thanks to his influence with his pupil Alexander the Great, he was able to command the great sum of eight hundred talents for the purchase of books and for other expenses involved in the preparation of his treatise on zoology. More than this, a thousand men throughout Asia and Greece studied under his direction the life and habits of birds and beasts, fishes and insects. ${ }^{2}$ The territories conquered by Alexander were carefully surveyed, by measuring the position of terrestrial objects with respect to stars. ${ }^{3}$ Although Aristotle maintained the fixity of the earth, and supposed comets and the Milky Way to be in its higher atmosphere,

2 Wheeler, "Alexander the Great," p. 37. The strict accuracy of these assertions, which were made by several classical authors, is questioned by Grote and also by Humboldt, who nevertheless concede that Aristotle received from both Philip and Alexander the most liberal support in procuring zoological material from Grecian territories and in the collection of books. "Cosmos," Sabine's trans., Vol. II., p. 158.

3 Bossut, "Histoire des Mathématiques," Vol. 1, p. 116. 
his reasoning in many astronomical problems was sound, as when he concluded that the earth must be spherical because its shadow on the eclipsed moon is always curved. ${ }^{4}$ Thus his studies of natural science foreshadowed the work of the present-day investigator and led to the most far-reaching results.

After his time a gradual division of labor ultimately separated investigations in natural science from the speculations of the philosophers. In Sicily, Egypt and the islands of the Mediterranean true scientific research, in the strictly modern sense, developed with remarkable rapidity, while in the old Lyceum at Athens the philosophy of reasoning and dialectics, earing little for physical causes, was devoted exclusively to the soul.

A deep-seated belief that the senses are deceptive, and the natural impatience of the Greeks, inclining them toward reasoning and speculation rather than the slow and laborious processes of observation and experiment, had first to be overcome. ${ }^{5}$ But in

4 Ibid., p. 117.

5 Weber, "History of Philosophy," Thilly's trans., p. 133 et seq. 
the third century B.c. the greatest geometer of antiquity, Archimedes, taught at Syracuse a system of astronomy closely resembling that of Copernicus, founded the science of mechanics in his treatise "De Aquiponderantibus," and devised some of the fundamental experimental methods of modern physics. At the same period Aristarchus of Samos made a first determination of the distance of the sun from the earth and held that "the center of the universe was occupied by the sun, which was immovable, like other stars, while the earth revolved around it." ${ }^{\prime}$ This view was also taught by Seleucus the Babylonian, but it was rejected by Ptolemy, the most celebrated astronomer of his day.

\section{THE MUSEUM OF ALEXANDRIA}

Of all the ancient prototypes of the modern academy, the great Museum of Alexandria holds the first place. Founded by Ptolemy Soter, whose preference would have confined its work to the moral and political sciences, its scope soon expanded under the influence of Ptolemy Phila-

- See Humboldt, "Cosmos," Vol. II., p. 309, and notes, p. cix. 
delphus and the pressure of circumstances, until it embraced the whole field of knowledge. ${ }^{7}$ Here almost all of the important results of Greek science were obtained in a period covering nine centuries. The museum established by Ptolemy was an extensive palace, housing the brilliant company of scholars and investigators gathered together from all parts of Greece. As a state institution, endowed with special revenues, it was under the direction of the government, which appointed its head. This, in accordance with the traditions of the day, was a priest, whose ecclesiastical office, and even the name of the museum itself, gave a kind of religious character to the institution, ${ }^{8}$ though it subsequently became purely secular.

Ptolemy Philadelphus collected strange animals from many lands, and sent Dionysius on exploring expeditions to the most remote regions. ${ }^{9}$ But while the investigators of the museum doubtless profited by these collections and explorations for their

7 Matter, "Histoire de l'Ecole d'Alexandrie," $2 \mathrm{~d}$ ed., Vol. II., Introduction, p. $\nabla$.

80 p. cit., Vol. I., pp. 87 and 96.

๑ Ibid., p. 158. 
studies in natural history and geography, Matter finds no evidence that at this period the museum possessed either a distinct natural history collection or a zoological park, ${ }^{10}$ though the study of medicine was encouraged, and a great art collection was developed.

The rising tide of science soon brought all the material requisites of research, supplementing the great library of 700,000 volumes by the instruments, laboratories and collections demanded by the astronomer, the physicist and the student of biology. A botanical garden, a zoological menagerie, an anatomical laboratory and an astronomical observatory in the Square Porch, provided by Ptolemy Euergetes with an equinoctial and a solstitial armillary, stone quadrants, astrolabes and other instruments, illustrate the nature of the extensive equipment provided. The work of the Alexandrian school thus continued to grow, until it embraced all of natural and physical science, medicine, mathematics, astronomy and geography, history, philosophy, religion, morals and politics. It is significant that an institution which in 10 Ibid., p. 159. 
many respects would be regarded as a model to be striven for to-day, should have developed at so early a period in the history of civilization. ${ }^{11}$

To the Alexandrian school we owe the "Geometry" of Euclid, and his treatises on "Harmony," "Optics" and "Catoptrics"; the hydraulic screw and some of the mathematical and physical discoveries of Archimedes of Syracuse, who spent part of his time in Egypt; the mathematical, astronomical, geographical and historical investigations of Eratosthenes, who first endeavored to determine the circumference of the earth by measuring the difference of latitude and the distance between Alexandria and Syene, and wrote on such subjects as the geological submersion of lands, the elevation of ancient sea-beds, and the origin of the Dardanelles and the Straits of Gibraltar; the "Conic Sections" of Apollonius; the mathematical and astronomical researches of Hipparchus, whose discovery of the precession of the equinoxes was based on observations made five hundred years previously by Timochares at Alexan-

11 Draper, "Intellectual Development of Europe," Vol. I., p. 188. 
dria ; and the great "Syntaxis" of Ptolemy, translated as the "Almagest" by the Arabians, which stood as a commanding authority in Europe for nearly fifteen hundred years. Founded on the geocentric hypothesis, the "Almagest" is nevertheless replete with astronomical methods and observations of the widest range and significance, and includes Ptolemy's discovery of the lunar evection, a rough determination of the distance of the earth from the sun, a masterly discussion of the motions of the planets, and a catalogue of 1,022 stars. These remarkable advances, which include only a fraction of the enormous scientific product of the Alexandrian school, were supplemented by equally striking contributions to literature and art. Philology, criticism and the history of literature became sciences, while the coming together of Buddhists, Jews, Greeks and Egyptians, with the most diverse beliefs, led to the development of comparative theology. Of the literary works of the Alexandrian school, the Septuagint and the poems of Theocritus are perhaps the most widely known. ${ }^{12}$

12 Recent works on Greek science include those of Tannery, Duhem, Lones and Heath. 
The rising power of Rome, which finally made of Alexandria a mere provincial town, was coincident with the decline of Greek intellectual life. In this paper only the more significant epochs in the development of academies can be mentioned, and we must pass over the work of the immediate successors of the Alexandrian school in Rome and Byzantium, and the achievements of Arabian science in Africa, Spain and Persia. In 1453, by the fall of Constantinople, where Greek scholars had preserved, in antiquated and pedantic form, the literary and philosophical traditions of the Alexandrian age, Italy was once more raised to its old position of "Magna Græcia." Some years earlier the scholar and ambassador Pletho, aided by Cosimo de Medici, had established a Platonic academy in Florence. Under this stimulus, and the influence of the Greek refugees, philosophy became popular, and Greek was widely studied. The voyages of Columbus, $\mathrm{Da}$ Gama and Magellan, and the astronomical achievements of Tycho Brahe, Copernicus, Kepler and Galileo reawakened the appreciation of scientific research and its possibilities. Leonardo da Vinci, 
continued the work of Archimedes and the Alexandrian school in optics, mechanics and other branches of physics, Vesalius established human anatomy on a firm foundation, and Harvey proved the theory of the circulation of the blood. It is not surprising that under such conditions academies of literature and science should multiply in Europe.

\section{ITALIAN ACADEMIES}

Among the earliest Italian academies were the academy of history, philology and archeology, founded in Rome by Pomponio Leto in 1457; the Accademia di S. Luca, devoted to the fine arts, established in 1577; and the Accademia della Crusca, founded in 1582, which has published several editions of its great Italian dictionary. ${ }^{13}$ In addition to these organizations seriously devoted to the encouragement of literature and the arts, a host of imitations sprang up all over Italy during the sixteenth century. Perhaps the gaiety of their proceedings was considered to find sufficient warrant in the 13 Carutti, "Breve storia dell'Accademia dei Lincei," p. 157. 
splendid suppers offered to the academy of Pomponio by the wealthy German Goritz, regarding which Ginguéné ${ }^{14}$ quotes the remarks of an earlier authority:

Ainsi, dit avec un juste sentiment de regret, le bon Tiraboschi, ainsi parmi les verres et les jeux d'esprit, on cultivait joyeusement les lettres, et les plaisirs mêmes servaient à en encourager et à en ranimer l'étude.

Leonardo da Vinci founded and directed the first scientific and experimental academy in Italy. ${ }^{15}$ Another early academy devoted to the pursuit of science was the Academia Secretorum Naturæ of Naples, which dates from 1560 .

Of special interest to the modern investigator is the Accademia del Cimento, which possessed a large collection of physical instruments, many of which are now preserved in the Galileo Museum at Florence. The "Saggi di Naturali Esperienze" made in the laboratories of this institution is an admirably illustrated account of early academic activities. The experiments; 14 Ginguéné, "Histoire literaire d'Italie," Vol. 7, p. 353.

${ }_{15}$ Libri, "Histoire des sciences mathématiques en Italie," Vol. 3, p. 30. 
which are described in great detail, with the aid of excellent woodcuts of instruments, are in some cases attributed to Galileo, Torricelli and other investigators, and in other cases are said to have been first performed in France. They include a wide variety of subjects, such as the effects of artificial freezing on various waters, wines, acids and oils, the compression of liquids, various phenomena in a vacuum, the electrical properties of amber, and the motion of projectiles.

This important volume was published in 1666, ten years after the establishment of the Academy, which lasted only during this period. The one great Italian academy of science which still survives is the Accademia dei Lincei, founded by Federico Cesi in 1603. His vast plans of organization for the Academy, resembling those of the religious and military orders of the day, are described in an unpublished work entitled the "Linceografo." The Academy was to comprise establishments in the four quarters of the world, where the members would lead a common life in the midst of libraries, museums, observatories, laboratories and botanic gardens, provided with 
every requisite means of research, and in constant communication with the other constituent bodies of the organization. The name Lincei, or Lynx-eyed, was taken in recognition of the reputation of the lynx for extreme penetration of vision, "vedendo non solo quello che è di fuori, ma anche ciò che dentro si asconde." 16

After a stormy period of youth, during which Cesi and his three fellow organizers underwent many vicissitudes, the Academy was vigorously revived in 1609 . Two years later, to its lasting renown, it was joined by Galileo, whose earliest telescopic discoveries had just been made. Under this stimulus, and aided by the widespread interest in Galileo's work, the Academy now advanced rapidly. While devoting special attention to the mathematical and physical sciences, it did not neglect the cultivation of literature, counting among its members historians, poets, antiquarians and philologists. Its cosmopolitan character is indicated by the diverse nationality of its membership, which was drawn from many of the nations of Europe. An Eng16 Carutti, "Breve storia dell'Accademia . dei Lincei," p. 8. 
lish member of this period was Francis Bacon. ${ }^{17}$

In November, 1612, Galileo communicated his discovery and observations of sunspots, which were published by the Academy under the title "Istoria e Dimostrazioni intorno alle Macchie Solari." The manuscript of this epoch-making discovery is still preserved by the Academy. This was followed in 1622 by his "Saggiatore," published in great haste, to avoid interference from the Church. Two years later he demonstrated at Rome the use of the microscope, so named by Fabri, a member of the Lincei. In 1629 Galileo completed his dialogue on "Due Massimi Sistemi del Mondo," and proposed to go to Rome to see it through the press. ${ }^{18}$

Limitations of space forbid mention of the memorable events of this time, during which the Academy supported Galileo in his difficulties with the Inquisition, and accepted the resignation of Valerio, who had attacked his doctrines. It was a stirring period, full of new and vigorous thought, which sharply conflicted with the

17 Carutti, op. cit., p. 26.

18 Ibid., p. 28. 
traditions of a vanishing age. Led by such men as Cesi, Porta, Galileo and Colonna, the Lincei played a prominent part in the development of the scientific advance of Italy and in the cultivation of the growing love of truth which spread throughout the civilized world. But in 1830 the Academy came to a sudden end, attributed by Carutti to the withdrawal of the patronage of Cardinal Barberini. ${ }^{19}$

Since that date it has seen several revivals, which are described in the history from which the present notice is derived. Reconstituted under Victor Emmanuel II. in 1875 as the Reale Accademia dei Lincei, it now flourishes as the national academy of Italy. The class of physical, mathematical and natural sciences has 55 members, 55 national correspondents, and $\mathbf{1 1 0}$ foreign members. The class of moral, historical and philological sciences has 45 members, 45 national correspondents and 45 foreign members. The president belongs to one class, the vice-president to the other, and each has a secretary and an assistant secretary. ${ }^{20}$

19 Op. cit., p. 97.

20 See revised statutes, Carutti, op. cit., p. 245. 
The home of the Lincei in the Palazzo Corsini is admirably adapted for the purposes of an academy. The collections include an extensive library, rich in rare books and manuscripts, and a large gallery of paintings, most of which is open to the public. The annual meeting, held in the great hall of the palace, is a very impressive function, attended by the King and Queen and other members of the royal family, whose keen and intelligent interest in the work of the Academy is a powerful incentive to increased effort and broader usefulness.

THE PARIS $\Lambda$ CADEMY OF SCIENCES

A brilliant and inspiring picture of the Paris Academy of Sciences at the zenith of its development and fame may be found in the opening chapter of Merz's "History of European Thought." 'This Academy, organized through the efforts of the far-seeing statesman Colbert at the period when Newton was engaged in the composition of his "Principia," has probably exerted a more favorable influence on the progress of science than any other similar institution in Europe. Enjoying both the moral and 
financial support of the French government, and permeated by an enthusiasm for scientific research which led its members to develop the most extensive cooperative projects, it offers a pattern which other academies may well seek to imitate. Great as it remains to-day, the period in its history which deserves our most careful consideration is that inspiring epoch, at the end of the eighteenth century, when France was everywhere recognized as the leader of the scientific world.

The academicians named by Colbert held their first informal meeting in the library of the Hotel Colbert in June, 1666. In the words of Fontenelle, heaven seemed to favor the rising company, which was fortunately able to observe two eclipses within the short interval of fifteen days. The second of these was observed with the aid of an instrument devised by Huygens (who was one of the members), and perfected later by Auzout and Picart-the well-known micrometer of the astronomer.

The original group, composed wholly of mathematicians and astronomers, was soon enlarged to sixteen, through the addition of Claude Perrault, Mariotte and other 
well-known chemists, physicians and anatomists. Laboratories and collections were established in the Bibliothèque du Roi, and the astronomical instruments were mounted in the garden, awaiting the completion of the great observatory designed by Perrault, where some of the meetings were subsequently held. Picart undertook the measurement of an are of the meridian which, when completed by Cassini, removed the last doubt of Newton as to the theory of gravitation. He was also sent to Denmark to determine the position of the ancient observatory of Tycho Brahe. Geographical maps were corrected and the latitudes and longitudes of a great number of points were measured. Richer went to Cayenne to determine the length of the pendulum and to make other observations. In short, the greatest activity reigned under the personal stimulus of Colbert, whose correspondence shows how large an amount of time he devoted to the interests of the Academy. Well-known names were added to the list of members, including those of Roemer, who determined the velocity of light from the eclipses of Jupiter's satellites; Cassini, the first of a remarkable lineage of astron- 
omers; the anatomist du Verney; and the great Leibnitz.

Under Louvois, the successor of Colbert, the Academy languished, but Bignon's plan of reorganization, adopted in 1699, inaugurated a new period of progress. The Academy was provided with quarters in the Louvre, where it remained until Napoleon assigned to the Institute the former College Mazarin, which it still occupies. Its unpublished memoirs were promptly printed, and were so favorably received by the public that as many as three editions were sometimes demanded. At this period a class of "associés libres" was established, to which such men as Turgot, the engineers Perronet and Belidor and Bougainville the explorer have since belonged.

During the eighteenth century the Academy attained a height only surpassed during the great epoch following the Revolution. Among the important events of this century were the mathematical researches of Clairaut and d'Alembert; the expeditions of Clairaut and Maupertuis to Lapland and of Godin, Bouguer and La Condamine to Peru, for the measurement of ares of the meridian; the similar under- 
taking of La Caille at the Cape, where he also determined the lunar parallax in cooperation with astronomers in the northern hemisphere and measured the positions of ten thousand stars; and the observations of the transits of Venus in 1761 and 1769 by Pingré at Rodrigues' Island, LeGentil in India, and Chappe in Siberia and California. The Cassinis continued their extensive astronomical and geodetic investigations in France, where the activity of astronomical research is illustrated by the fact that when Bernouilli came to Paris in 1760 he found, in addition to the original observatory, eight or ten other observatories engaged in investigation under the direction of academicians. Lalande, known as a severe critic, wrote in 1766 :

The collection of Memoirs of the Academy of Sciences is the richest storehouse of astronomical knowledge that we possess.

But the work of the Academy was by no means confined to astronomy and its sister sciences. Through the investigations of its chemists, the way was prepared for the creation of modern chemistry by Lavoisier. Réaumur, Buffon and their contemporaries were making extensive contributions to 
natural history, while Haüy was laying the foundations of mineralogy. At the same time Geoffroy and the three Jussieus shared with Linnæus the honor of creating the science of botany.

Under such conditions it is not surprising that the nation should turn to the Academy for assistance and guidance in many of its enterprises. Ministers, parliaments, administrators and state assemblies often sought its aid and accepted its decisions. So commanding was its position that when all the academies were suppressed under the Revolution, it was stipulated that the Academy of Sciences should provisionally continue its functions and receive its annual revenues from the state.

As there are still those who see in a national academy a menace to true democracy, and who criticize our own National Academy on this score, the attitude of the revolutionists toward the Paris Academy is not without interest. In the report on public instruction made by Talleyrand to the National Assembly in 1791, on behalf of the committee, it was proposed to establish a National Institute to continue and extend the functions of the various exist- 
ing academies. ${ }^{21}$ In a later report on behalf of the Committee on Public Instruction, Condorcet showed that the only satisfactory method of determining the membership of such an academy is to leave the elections to the members themselves. ${ }^{22}$ Article 298 of the Constitution, adopted August 22, 1795, declares :

Il y a pour toute la République un Institut national chargé de recueillir les découvertes, de perfectionner les arts et les sciences.23

This differed from the former group of academies mainly in the unity of the academic body, which covered the whole range of knowledge (though the Académie Française was not represented), and the equality in number and privilege of the members resident in Paris and the non-resident members of the provinces. ${ }^{24}$ Far from losing its prestige through the effects of the Revolution, the Academy of Sciences rose to its greatest success in the years follow-

21 Hippeau, "L'instruction publique en France pendant la révolution," Vol. I., p. 102.

22 Ibid., p. 327.

${ }^{23}$ Simon, "Une Académie sous le Directoire," p. 39.

24 Simon, op. cit., pp. 44, 46, 50. 
ing the Terror, and formed, with its sister academies, the chief connecting link between the modern democracy and the old régime. ${ }^{25}$

The National Institute, as thus constituted, lasted until 1803, when Napoleon Bonaparte again reorganized it. The members of the first class (Academy of Sciences) were grouped in two divisions, containing eleven sections in all. The two secretaries, no longer connected with any section, were made permanent. This organization, with no essential change, still remains in force. The law of 1803 suppressed the national associates, replacing them in the case of the Academy of Sciences by 100 correspondents (national and foreign), increased to 116 in 1899.

It is interesting to remember that Napoleon took an active part in the Academy of Sciences, of which he was elected a member in 1797. During the expedition to Egypt he invariably signed himself "Le membre de l'Institut, général en chef." ${ }_{26}$ His appreciation of the importance of scientific

25 Maury, "L'ancienne Académie des Sciences," p. 1.

26 Simon, op. cit., p. 40. 
research is amply illustrated by the distinguished company of investigators which he took with him on this expedition, where he organized the Institute of Egypt in Cairo, and proposed to establish an astronomical observatory. ${ }^{27}$ The extensive and superbly illustrated report of his investigators on the antiquities of Egypt was the first great step in Egyptian archeology, leading to the successful labors of Champollion, Mariette and Maspero, and the dominance of the French school in Egypt even under British control.

In the great days of the First Empire began the brilliant period in the history of the Academy which Merz so justly emphasizes. With such members as Lagrange, Laplace, Legendre and Cauchy in mathematics; Messier, Arago, Lalande and Delambre in astronomy; Biot, Ampère, Fourier, Fresnel, Becquerel and Regnault in physics ; Berthollet, Gay-Lussac, Dulong, Dumas and Chevreul in chemistry; Cuvier, de Jussieu, Lamarck and Geoffroy SaintHilaire in biology, and with others equally celebrated in other fields, it is not surprising that the Academy commanded the 27 "Mémoires sur 1'Egypte," Paris, An VIII. 
respect and the admiration of the civilized world.

Some of the elements which have entered into the success of the Paris Academy are not difficult to recognize: the sympathy and support of such statesmen as Colbert and Napoleon, who appreciated the fundamental importance of science to the nation, as Alexander the Great and the Ptolemies had done before them; the cooperative spirit which led the members to work together for a common cause; the perfection in the hands of the academicians of the powerful mathematical methods which contributed so largely to the application and widespread usefulness of Newton's discoveries; and the popularization of science and the diffusion of the scientific spirit through the brilliant writings of Cuvier, Laplace, Buffon, Fontenelle and many others. Far from disdaining the translation of technical papers into attractive literature, these great leaders set an example which was followed hardly less effectively, though in a different manner, by Davy and Faraday at the Royal Institution. Cuvier, above all others, represented the academic system at its best. In his 
eloquent Eloges on the most eminent scientific men of the day, he paints a picture of scientific investigation and progress with the hand of a practised artist. The wide field of science, and the rich results flowing from the labors of investigators skilled in many departments of knowledge, has never been more admirably depicted than in the discourses of this distinguished perpetual secretary. ${ }^{28}$

\section{GERMAN ACADEMIES}

In Germany, the division of the empire into many kingdoms, preventing the centralization which has been so important a factor in France and England, and the prevailing influence of the universities as research laboratories, where every teacher is not only a scholar but a productive investigator, have stood in the way of the development of a single dominant national insti-

28 For the data used in this account of the Paris Academy I am largely indebted to the work of Maury, Simon, Merz and Hippeau, already cited, and especially to the article by Darboux in "L'Institut de France," Vol. 2 (Paris, 1907). See also the useful series of articles by Dr. E. F. Williams on the Paris, Berlin and Vienna Academies in the Popular Science Monthly. 
tution like the Paris Academy of Sciences.

During the eighteenth century the great men of science, including Leibnitz, Euler, Haller, Tobias Mayer, Lambert, Olbers and Alexander von Humboldt, were widely scattered, and in most cases had little to do with the universities, although these were already distinguished for classical scholarship. But by the publication of his "Disquisitiones Arithmeticæ," and the invention of his improved method of calculating planetary orbits, Gauss, of the University of Göttingen, placed himself on a level with the great French mathematicians and inaugurated a new era in German science. By the use of this method, von Zach and Olbers were enabled to recover the first of the minor planets, Ceres, which had been lost on its approach to the sun. Gauss also introduced exact science into the university curriculum, but it was through the work of Jacobi that the great school of German mathematicians was set on foot a quarter of a century later. The contemporary establishment of chemical laboratories by the universities, and the widespread influence of Liebig, Mitscherlich and Wöhler in chemistry, and of Schleiden and Schwann 
in botany and zoology, determined for all time the place of the German university in science. Schleiden's cell theory of plant structure and growth was the source of a long series of discoveries, which established the supremacy of Germany in physiology. ${ }^{29}$

In spite of the unfavorable conditions already mentioned, four great academies have nevertheless arisen in Germany, those of Berlin, Munich, Leipzig and Göttingen. Among these, partly because of the leadership of Prussia in the German empire and partly from other causes, the Berlin Academy stands foremost. Founded in 1700 as the Societas Regia Scientiarum, through the influence of Leibnitz and in accordance with his plans, it has contributed in the highest degree to the advancement of German scholarship. Its present designation as "Akademie der Wissenschaften" indicates the broad scope of its activities. The fifty regular members are divided into two classes, each of which consists of two sections, presided over by a permanent secretary. The first class comprises the sections of physics and mathematics, the second 29 See Merz's "History of European Thought," Vol. 1, Chap. 2. 
those of philosophy and history. The secretaries preside in turn at the meetings of the separate classes, and at the general meetings, which are held monthly. Each member receives an annual stipend of 900 marks, while the secretaries are paid larger salaries. There are also two positions carrying salaries of 12,000 marks each, filled by the astronomer and the chemist of the Academy, and a dozen similar pensions which may be distributed at discretion.

In the early days of its history, the Berlin Academy devoted most of its resources to the establishment and maintenance of research laboratories and museums. Its headquarters were originally in the Berlin Observatory, which was conducted under the direction of the Academy, and it also acquired anatomical and zoological collections, a mineralogical museum, and a botanical garden. Furthermore, the chemist of the Academy conducted his researches in a chemical laboratory provided for the purpose. ${ }^{30}$ In 1809, when the University of Berlin was established to compensate for the loss of Halle by the treaty of Tilsit, 30 See Harnack's great "Geschichte der Berliner Akademie der Wissenschaften." 
these functions of the Academy were transferred to the University and have since remained under its direction. In an interesting and important manuscript by Wilhelm von Humboldt, entitled "Ueber die innere und äussere Organization der wissenschaftlichen höheren Anstalten in Berlin," his ideas on the relationship between the Academy and the newly organized University are fully set forth. Schleiermacher had defined the university as a group of students, the academy as a group of investigators: the former concerned with the diffusion of knowledge, and the stimulation of scientific research, the latter with the development of scientific problems themselves. Humboldt believed the main distinction between the two bodies to lie in their form and their relationships rather than in their work. The university always remains in close relationship with practical life and the necessities of the state, since it is engaged in the practical task of educating the youth of the nation, while the academy is concerned solely with knowledge.

When only the function of teaching and disseminating knowledge is assigned to the univer- 
sity and its promotion to the academy, injustice is manifestly done the former. ${ }^{31}$

Whereas the university teachers are under common bonds only in the matter of discipline, and are quite independent of one another in other respects, the academy is a society each member of which must submit his work to the judgment of all. Hence, he insists, the idea of an academy as the highest and ultimate freehold of knowledge, and as a corporation which is more independent than any other of the state, must be maintained.

In Humboldt's view, a close interchange of activities between academy and university should be provided for. Each academican must have the right to lecture at the university without going through the ordinary preliminaries, and without involving any direct connection with it. Many scholars should be both university professors and academicians, but both institutions should have other members who belong to it alone. The academy must be free to choose its own members, subject only to the approval of the government, 31 Paulsen, “The German Universities," trans. by Thilly and Elwang, p. 53. 
while professors in the university should be appointed exclusively by the state. ${ }^{32}$

In spite of the transfer of some of its principal departments to the University of Berlin, the Berlin Academy has by no means relinquished its important object of carrying on large research projects. As already stated, it still has an endowed professorship of chemistry, recently held by van't Hoff, and now by Fischer, and a professorship of astronomy, held by Auwers. Both of these investigators pursue their researches under the auspices of the Academy. The great work upon which Professor Auwers is engaged is characteristic of many of the larger undertakings of the German academies, to which they devote nearly half of their available funds. This is the "Geschichte des Fixsternhimmels," an immense catalogue of star positions based upon the observations of many astronomers. Similar undertakings by the Berlin Academy in other fields are the "Corpus inscriptorum græcarum" and the "Corpus inscriptorum latinarum." The preparation of a great edition of Aristotle's works, 32 Lenz, "Geschichte der Universität Berlin," Bd. I., pp. 186-188. 
begun by the Berlin Academy in 1821 and finished in 1909, is cited by Diels as a most striking illustration of the advantage of academic continuity, with which no individual can hope to compete. ${ }^{33}$ For such an undertaking, which we have come to regard as characteristically German, an organized body like an academy of sciences possesses, not merely the advantage of continuity, but that which results from the combined experience and the wide range of vision brought to bear through the cooperation of many eminent authorities. An academy may also command far more extensive material than would fall within the reach of the individual worker. This phase of academic activity, practised in different forms in the Museum of Alexandria and, in the preparation of national dictionaries, by the Académie Française and the Accademia della Crusca, is also illustrated in England by the Royal Society's "Catalogue of Scientific Papers." Our own National Academy has yet to take any steps in this direction.

33 Diels, "Die organisation der Wissenschaft," in "Die Allegemeinen Grundlagen der Kultur der Gegenwart,"' $2 d$ ed., p. 667. 
The importance attached to this form of academic work in Berlin is clearly illustrated in the plans of the new academy building, for a set of which I am indebted to the kindness of Professor Diels. This building, which is being constructed in connection with the new Royal Library, is probably more perfectly adapted for academic purposes than any other building now in use, as it was especially designed for the work to be carried on in it. $^{34}$ The plans show that one room each is to be devoted to the Corpus medicorum Grocorum, the Acta Borussia, and the Plant Kingdom, three rooms to the Corpus inscriptorum Latinarum, four to the Oriental Commission, four to the Egyptian Dictionary, eleven to the Inscriptiones Grocca, eleven to the German Commission, two to the edition of Leibnitz's collected works, seven to the History of the Fixed Stars. In addition to all of these rooms for special research, there are the great "Fest Saal," separate meeting rooms for the two classes of the Academy, a general meeting 34 Most of the European academies are housed in palaces or similar buildings formerly used for other purposes. 
room for both classes together, a large anteroom, a demonstration room, seven editorial rooms, four secretaries' offices, offices for the registrar, the recorder and the chancellor, a reading-room and large library and stack room, a correspondence room, an instrument room, a photographic laboratory, and various other offices, kitchens, servants' rooms, etc.

It is a significant fact that Merz, after devoting an eloquent chapter to the evolution of science in France under the stimulus of the Paris Academy, barely mentions the German academies when discussing the progress of science in that country. The reason, as we have already seen, lies in the predominating influence of the universities in the development of German scientific life and thought. With every teacher an investigator, every university a laboratory of research, and with the powerful aid of the state encouraging in every possible way the prosecution of investigation no less than the instruction of students, it is easy to see how the universities obtained their ascendancy in the field of science, or rather in the broad field of Wissenschaft, for in 
Germany the same spirit of research has permeated every department of knowledge. The wide distribution of the universities and their considerable number, together with the free interchange of professors and students, have worked against centralization, and have served to create a cosmopoli$\tan$ spirit in striking contrast with that which obtains in France. One can hardly fail to believe that no single influence could be more effective than the universities for the development of the latent capacity of a nation for scientific research. But while the German academies have doubtless suffered by contrast with the universities, a survey of the intellectual progress of Germany should by no means overlook the invaluable services the academies have rendered.

It would seem, however, that these services might have been even greater if a larger number of the scientific men of the nation could have taken an active part in the work of the academies. As at present constituted, the membership of these bodies is extremely limited, and each member must reside within a very short distance of the 
seat of the academy, so that he may be able to attend the meetings regularly. These limitations, though not without compensating advantages, are in striking contrast with the wider membership and freer interchange which seem to have been essential elements in the extraordinary development of the university system.

\section{THE ROYAL SOCIETY}

When we pass to England, and examine the history of intellectual progress, we find a fundamentally different condition of affairs. This reflects the natural characteristics of the English people, just as the university system of Germany and the academic activities of France illustrate the essential qualities of these nations. Merz's picture of the growth of scientific research in England is in some respects a somber one. In his view the Royal Society appears to have played no part in advancing the intellectual life of the nation and the Royal Institution, as well as Oxford and Cambridge, fare little better at his hands.

Now no one will attempt to deny that the characteristic quality of British science has always rested in the individual, and 
that organized efforts there have played a less conspicuous part than in France or in Germany. During a large part of their history, Oxford and Cambridge have done little for research, though the past half century has seen a remarkable change in this respect, particularly in the ease of the Cavendish laboratory, whose succession of brilliant leaders can hardly be matched in the history of any other university laboratory. Men whose names are famous in science have sprung up in the most unexpected places, without ancestry, training or encouragement to account for the dominant influence they have exerted on the scientific thought of the world. A notable illustration of this kind is afforded by Faraday, whose obscure origin, extreme poverty, and lack of the assistance of schools, were most fortunately offset by his transcendent genius and by the influence of Davy, whose lectures at the Royal Institution soon transformed the bookbinder's apprentice into Davy's able successor. Darwin, though of distinguished ancestry, was another English "amateur" whose work was done apart from the universities. 
A host of others might be mentioned, whose extraordinarily original contributions to scientific thought have found few equals in other lands. For the most part, they have worked alone and sometimes unaided, and their great results have been achieved in spite of conditions which may appear unfavorable and discouraging. But in my opinion the Royal Society and the Royal Institution, not to speak of other important agencies, such as the societies devoted to special branches of science, have exercised in England a profoundly favorable influence which can not be ignored.

In failing to take note of this in his classic work, Merz seems to exhibit some traces of a pessimistic quality which is sometimes encountered in English life. It is mainly to short-sightedness of the government and to individual conservatism that I should be inclined to charge that lack of support of scientific men of which Merz so feelingly complains, rather than to the Royal Society and other organized bodies for the promotion of science. As a matter of fact, it is easy to show that these institutions 
have exerted a powerful stimulus, without which the progress of science in England undoubtedly would have been delayed.

In the first place, the Royal Society has extended the distinction and privileges of its fellowship to a much larger number of investigators than have been similarly honored by the continental academies. ${ }^{35}$ Every investigator in science will understand and appreciate the benefit which such recognition entails. Most of all the obscure individual worker, unnoticed and unsupported by the universities, but wholly devoted to the pursuit of science, must benefit by such moral support. On the continent I have known investigators of this type, not connected with a university, and receiving no aid or encouragement from neighboring university men, who could not be recognized by election to the academies because of their limited membership or their fixed traditions. In England many such men have been received into the Royal Society, which has been glad to publish their papers as Fellows and to aid them in other ways.

35 Fifteen new members are elected annually, making a total membership of 477 (Jan. 1, 1913). 
A notable illustration is afforded by the case of Newton, elected a Fellow of the Royal Society on January 11, 1671, and subsequently its president for the long period of twenty-four years. A month following his election, Newton communieated to the Society his discovery of the composite nature of white light, which, when published in the Philosophical Transactions, was the first of his productions to appear in print. In expressing his thanks to the Society, Newton remarked: $:^{30}$

It was an esteem of the Royal Society for most candid and able judges in philosophical matters, that encouraged me to present them with that discourse of light and colors, which since they have so favorably accepted of, I do earnestly desire you to return them my most cordial thanks. I before thought it a great favor to be made a member of that honorable body, but I am now more sensible of the advantage: for believe me, Sir, I not only esteem it a duty to coneur with them in the promotion of real knowledge, but a great privilege, that, instead of exposing discourses to a prejudiced and censorious multitude (by which means

36 Weld, "History of the Royal Society," Vol. I., p. 237. Brewster's "Life of Newton" gives an interesting account of Newton's relations with the Royal Society and his plan for its improvement (Vol. I., p. 102). 
many truths have been baffled and lost), I may, with freedom, apply myself to so judicious and impartial an assembly.

Leuwenhoeck, "the father of microscopical discoveries," who communicated no less than 375 papers and letters to the Society during a period of fifty years, bequeathed a collection of microscopes "as a mark of my gratitude, and acknowledgment of the great honor which I have received from the Royal Society." "37

When the Royal Observatory was established at Greenwich, the government failed for a period of nearly fifteen years to furnish it with a single instrument. In this extremity Flamsteed appealed to the Royal Society, with the following result recorded in the minutes:

It was ordered that the astronomical instruments belonging to the Society be lent to the Observatory at Greenwich, and that Mr. Hooke's new quadrant be forthwith finished at the charges of the Society. 38

Examples of this nature might be multiplied indefinitely, but a single case will suffice, since no more striking instance

37 Weld, ibid., p. 245.

38 Weld, ibid., p. 255. 
of the splendid results directly due to the encouragement and aid of the Royal Society could be asked than that illustrated in the life and work of Sir William Huggins, one of the founders of astrophysics, and a typical example of the English "amateur" investigator. ${ }^{39}$ Sir William, to whose addresses as president of the Royal Society we shall have occasion to refer later, was not a university man. With his accomplished wife as his only assistant, he lived and did all his work at Upper Tulse Hill, well removed from the bustle of Piccadilly on the Surrey side of the Thames. It is more than probable that without the stimulus and aid of the Royal Society much of his great work could not have been done. For it was on returning home from a Royal Society meeting in company with his friend Miller that he first conceived the idea of observing the spectra of stars, and it was with telescopes and other instruments loaned to him by the Society that his classic observations were

$39 \mathrm{It}$ is hardly necessary to say that the term "amateur" is used here to denote one who works in science for the pure love of the subject, and not in the sense of dilettante. 
made. In spite of fogs and clouds of London smoke, he continued his work up to the very end of his long life, dividing his allegiance to science only between his astrophysical investigations and the development of the Royal Society, of which he was for forty years a leading Fellow.

Thus, in spite of that early poverty which prevented the Royal Society from publishing the "Principia" of Newton, it has lent its powerful aid and support to many a British investigator, who without it would have been absolutely isolated. Its large collection of instruments, the accumulation of more than two centuries, is freely placed at the disposal of those who need them. Its Philosophical Transactions and Proceedings have furnished the most desirable means of publication for an enormous mass of scientific literature. Its meetings bring together every Thursday at Burlington House the leading scientific men of the kingdom, and furnish an opportunity for stimulating interchanges of view which have played a great part in scientific progress. Its various gold medals, impartially bestowed at home and abroad, in 
recognition of advances in science, have been effectively supplemented by financial assistance to investigators from the Government Grant Fund of $£ 4,000$ per annum, which is administered by the Society. To its influence is largely due the high standard of efficiency maintained by the government in its appointment of astronomers royal and other directors of the scientific research of the nation. When the government decided to establish a National Physical Laboratory it turned at once to the Royal Society, to which it delegated the planning and control of this great institution. Its Catalogue of Scientific Papers, continued as the International Catalogue of Scientific Literature, has contributed in a most important way to the accessibility and usefulness of the literature of science, and is indispensable to every investigator. It has supplied both money and instruments to scientific expeditions sent to all parts of the globe, and provided for the suitable reduction and discussion of the observations obtained. It has aided the government of India in the work of the Indian Meteorological Department and 
participated with the meteorological office in the direction of the work of the $\mathrm{Kew}$ and its sister observatories. The reports of its Sleeping Sickness Commission have advanced in an important degree our knowledge of tropical diseases. In fact, one could point to an almost unlimited number of illustrations of the beneficent activities of the Royal Society as the leading representative of British research, and as one of the most powerful factors in broad projects of cooperation, such as those of the International Association of Academies.

Unlike the academies of St. Petersburg, Berlin, Vienna and Stockholm, which maintain large research laboratories or support research professorships, the Royal Society has no laboratories of its own. Closely allied with it, however, is the Royal Institution, formerly known as "the workshop of the Royal Society." No laboratory in existence can match its extraordinary record, accomplished at an almost incredibly small cost. ${ }^{40}$ When one recalls Young's great work in laying the founda40 Dewar, address as president of the British Association, Belfast, 1902, p. 11. 
tion of the wave-theory of light, not to speak of his success in discovering the first clue to the translation of Egyptian hieroglyphics; Davy's long series of discoveries in chemistry, and his public lectures and demonstrations; Faraday's great achievements in physical and chemical research, and the dignity and luster he imparted to the popular presentation of scientific results to a general audience; Tyndall's success in the same lecture-hall, and his services in popularizing science in the United States; and the long series of important investigations, especially in the fruitful field of low temperature phenomena, which we owe to Dewar, who has now occupied the chair of chemistry even longer than Faraday: these form a record remarkable in the annals of science, with returns so rich as to be worthy of the expenditure of almost any sum. But even this long list does not represent the total product of the laboratory, where such eminent leaders as Lord Rayleigh and Sir Joseph Thomson have also conducted investigations of the first importance. So far as my, own observations have gone, no 
other laboratory holds a more tangible atmosphere of research or stimulates more powerfully the imagination of the visitor. I shall have occasion later to refer to the equally remarkable success of the Royal Institution in diffusing and popularizing knowledge through its courses of experimental lectures.

Academies of the first class are so numerous that only a few of the oldest organizations, whose work bears directly upon the problems of our own National Academy, can be mentioned in this paper. I hope to have opportunity at some future time to describe the work of such influential bodies as the Vienna Academy, which has founded a Radium Institute and taken steps which should result in the establishment of a Solar Observatory; the Stockholm Academy, entrusted with the responsibility of awarding the Nobel Prizes in physics and chemistry; the Amsterdam Academy, focus of the great research work of Holland; and many other academies of the highest rank representing the various nations of Europe. For the present I must limit attention to a group of institutions which suffice to typify the wide 
range of academic activities. However, a word must be added regarding the St. Petersburg Academy, established by Catherine I. on the plans of Peter the Great in 1725 , because of its special plan of organization. The president, director and fifteen members are paid annual stipends ranging from one thousand to three thousand dollars, and provided with dwelling houses. The great academy building, with its library of over 36,000 books and manuscripts, contains large laboratories in which investigations are constantly in progress. The extensive publications include researches in every field of knowledge and exhaustive memoirs on the topography, geography and history of Russia and the manners, customs and languages of its various peoples.

\section{THE PURPOSE OF ACADEMIES}

From this survey of the work of a few . of the leading academies and allied institutions, we see that original investigations have played a large part in their activities, from the days of the great Museum at Alexandria to the present time. In certain instances, illustrated in the history of the 
University of Berlin, some of the work of investigation has been transferred from the academies to the universities, but without interrupting the larger activities of the academies in the same field. Again, in cases like that of the Royal Society, the development of a closely allied laboratory of research, such as the Royal Institution, has partially supplied the place which a laboratory under the exclusive control of the Society might have held. The essential thing to note is the advantage which results from the organic relationship of an academy with a laboratory for the production of new knowledge. An academy will reach its greatest influence, and serve its most useful purpose in stimulating the work of its members, when it is recognized as an institution primarily "for the increase" rather than "for the diffusion of knowledge among men."

In the field of publication, the national academies of former times were predominant factors, so much so that we owe to their printed pages the great volume of the original contributions of the earlier days of science. With the rapid extension of 
the facilities for investigation, and the extensive ramifications of science into special fields, the societies and journals devoted to particular lines of research naturally arose and multiplied. The prestige of such publications as the Proceedings and Transactions of the Royal Society fortunately enables them to hold their own, in spite of the competition of so many journals devoted to special subjects. And the opportunity afforded by academies for the publication of extended memoirs beyond the range of ordinary periodicals, is universally appreciated. As regards shorter communications, the peculiar claims of the special journals, which have been proved by time to serve the purposes for which they were designed, would naturally receive consideration in elaborating any new plan of academic publication to meet existing needs. This subject will be more fully considered in a later paper.

In the management and distribution of trust funds for research, the loan of instruments, the award of prizes, and especially in the advice of governments and individuals as to the best means of initiating and 
conducting scientific enterprises, national academies occupy a position which private foundations can hardly hope to rival. The value of advice received from a body of the highest reputation and prestige is greatly enhanced, because of the increased probability that it will be heeded and carried into effect. For a similar reason, recognition of individual achievement through the award of prizes or election to membership acquires its greatest weight when received from such a body.

After reviewing all of the activities which we see so diversely exemplified by the national academies of different countries, the conviction is forced upon one that the first and best object of these bodies must always be to uphold the dignity and importance of scientific research, and to diffuse throughout the nation a true appreciation of the intellectual and practical benefits which will inevitably result from its support and encouragement. But to accomplish great results in this field, an academy must enjoy the active cooperation of the leaders of the state. To appreciate this, we have only to remember the many striking illustrations afforded in the history of civilization. What was done by 
Alexander the Great and the Ptolemies for Egypt, by the house of Medici for Italy, by Richelieu, Colbert and Napoleon for France, can be done for other nations by living statesmen to-day. In the midst of his campaigns Napoleon never forgot the paramount claims of science and the fine arts. Writing to the astronomer Oriani from Milan, which he had entered in triumph, Napoleon said:

The sciences which do honor to the human mind and the arts which embellish life and perpetuate great achievements for posterity, should be especially honored under free governments.

... I invite the scholars to meet and to give me their opinions as to the means that should be taken, and the needs to be fulfilled, in order to bring new life and activity into the sciences and the fine arts. Those who wish to go to France will be received with distinction by the government. The French people sets a higher value on the acquisition of a skilled mathematician, a celebrated painter or a distinguished man of any profession, than upon the possession of the largest and richest eity.41

This article can not be better closed than by a quotation from Laplace, the most distinguished member of the Paris Academy in its brilliant days under the first empire.

41 Maindron, "L'Académie des Sciences," 205. 
Nature is so varied in her manifestations and phenomena, and the difficulty of elucidating their causes is so great, that many must unite their knowledge and efforts in order to comprehend her and force her to reveal her laws. This union becomes indispensable when the progress of the sciences, multiplying their points of contact, and no longer permitting a single individual to understand them all, throws upon a group of investigators the task of furnishing the mutual aid which they demand. Thus the physicist appeals to the mathematician in his efforts to arrive at the general causes of observed phenomena, and the mathematician in his turn consults the physicist, in order to render his investigations useful by practical applications, and in the hope of opening up new possibilities in mathematics. But the chief advantage of academies is the philosophic spirit which must develop within them, thence diffusing itself throughout the nation and permeating every interest. The isolated scholar may yield with impunity to the tendencies of the systematist, since he hears only from afar the criticism that he arouses. But in an academy the impact of such tendencies ends in their destruction, and the desire for mutual conviction necessarily establishes the rule of admitting only the results of observation and calculation. Furthermore, experience has shown that since the origin of academies the true spirit of philosophy has prevailed. By setting the example of submitting everything to the test of severe logic, they have overthrown the preconceived notions which too long dominated science, and were shared by the ablest 
minds of previous centuries. Their useful influence on public opinion has dissipated errors greeted in our own time with an enthusiasm which would have perpetuated them in earlier days. Equally removed from the eredulity which denies nothing and the conservatism which would reject everything that departs from accepted ideas, they have at all times wisely awaited the result of observation and experiment on difficult questions and unusual phenomena, promoting them by prizes and by their own researches. Measuring their approval no less by the greatness and difficulty of a discovery than by its immediate utility, and convinced, by many examples, that what appears to be least fruitful may ultimately yield important consequences, they have encouraged the pursuit of truth in all fields, excluding only those which the limitations of the human understanding render forever inaccessible. Finally, we owe to them those great theories, elevated by their generality above the comprehension of the layman, which through numerous applications to natural phenomena and the arts, have become inexhaustible sources of happiness and enlightenment. Wise governments, convinced of the usefulness of scientific societies, and regarding them as one of the principal causes of the glory and prosperity of empires, have established such bodies in their very midst, in order to profit by their counsel, which has often brought lasting benefits. 42

42 “'Exposition du Système du Monde," Oeuvres, Vol. VI., p. 418. 
II. THE FIRST HALF CENTURY OF THE NATIONAL ACADEMY OF SCIENCES

In the days preceding the American Revolution, the Royal Society was to this country what it still is to the existing British Colonies: the central and authoritative representative of scientific research. ${ }^{1}$ Americans eminent for their contributions to science were elected Fellows, and their papers appeared in the Philosophical Transactions. The list of colonial Fellows includes Cotton Mather, Bowdoin, Dudley, and the three Winthrops in New England; Franklin, Rittenhouse and Morgan in Pennsylvania; Banister, Clayton, Mitchell

1 See an excellent article by G. Browne Goode, from which the data used in the introduction of the present paper are taken: "The Origin of the $\mathrm{Na}$ tional Scientific and Educational Institutions of the United States," Annual Report of the American Historical Association for 1889. 
and Bird, in Virginia, and Garden and Williamson in the Carolinas. But sodistant a body could not meet all local needs. Thus Franklin, active in every field, undertook the organization of the American Philosophical Society in 1743 , some years before its time, as its early demise proved. In $\mathbf{1 7 6 6}$ the American Society held at Philadelphia for Promoting Useful Knowledge was established and Franklin, then in Europe, was elected its first president. In the meantime the earlier society was revived, and the amalgamation of the two in 1769 gave rise to a scientific body which has always exercised a powerful and beneficent influence on the progress of science in the United States. The prominence in the affairs of state of its leading members is illustrated in the frequent interruptions to the proceedings of the society between 1773 and 1779 , when these men, who included Washington, Franklin, Jefferson and Adams, were occupied with the labors of organizing the new republic. The American Philosophical Society, modelled after the Royal Society, but embracing the whole field of knowledge, soon assumed great 
importance at its seat in Philadelphia, then the center of American scientific and literary life.

John Adams, when representing the United States in France, learned of the appreciation in which the Philosophical Society was held in academic circles. On his return to Boston in $\mathbf{1 7 7 9}$ he suggested the establishment of the American Academy of Arts and Sciences, which was duly incorporated by act of the Massachusetts State Legislature in 1780. At this time the influence of France was naturally more potent than that of England, and the Academies of Paris were chosen as models by the charter members of the new organization.

The year 1778 marks the inception of an ambitious plan, proposed by the Chevalier Quesnay de Beaurepaire. His scheme for the Academy of Arts and Sciences of the United States had been endorsed by the King of France, the Royal Academies of Science and of the Fine Arts, and by Lavoisier, Condorcet and many eminent Frenchmen. The sum of sixty thousand francs was subseribed by wealthy Virginians, and a building was erected in Rich. 
mond in 1786. One (French) professor was appointed to make natural history collections and extensive plans for branch establishments in Baltimore, Philadelphia and New York were contemplated. But the French Revolution put an end to this intellectual exotic.

In the present paper, devoted primarily to the history of the National Academy, we must pass over many interesting developments in the early scientific life of the nation. Reference must be made, however, to the incorporation of the American Association for the Advancement of Science in 1848 , and to the intense vitality which has enabled this body, in cooperation with many special societies of later origin, to bring the results of scientific research within the reach of an ever-widening public.

Alexander Dallas Bache, superintendent of the United States Coast Survey from 1843 to 1867, and one of the leading spirits of his time, was among the first to express publicly the demand for a national organization of American research officially recognized as such by Congress. ${ }^{2}$ In his

${ }^{2}$ For most of the material in the following pages the writer is indebted to a history of the "First 
presidential address to the American Association for the Advancement of Science in $\mathbf{1 8 5 1}$ he emphasized the need of "an institution of science, supplementary to existing ones, to guide public action in reference to scientific matters."

Suppose an institute of which the members belong in turn to each of our widely scattered states, working at their places of residence and reporting their results; meeting only at particular times, and for special purposes; engaged in researches self-directed, or desired by the body, called for by congress or by the executive, who furnish the means for the inquiries. . . The public treasury would be saved many times the support of such a council, by the sound advice which it would give in regard to various projects which are constantly forced upon their notice, and in regard to which they are compelled to decide without the knowledge which alone can ensure a wise conclusion.

... Such a body would supply a place not occupied by existing institutions, and which our own

Half Century of the National Academy of Sciences," prepared and edited by Frederick W. True, under the direction of Dr. Arnold Hague, then Home Secretary, in connection with the recent celebration of the fiftieth anniversary of the founding of the Academy. 
is, from its temporary and voluntary character, not able to supply. 3

As president of the American Association, and as a prominent member of the American Philosophical Society and the American Academy of Arts and Sciences, Bache entertained no misconception regarding the admirable aims and the no less admirable successes of these older societies. Each performed then, as it does now, a useful function of broad scope, which the proposed organization was not to rival but to supplement. The American Philosophical Society continues to exert a wide and useful influence, drawing to its annual meetings in Philadelphia a large body of able men representing every field of knowledge. Its strong vitality and its traditions of a scholarly past are shared by the American Academy, now rapidly increasing in membership and advantageously established in the permanent home provided for it in Boston by Alexander Agassiz. The American Association, like the British Association for the Advance-

$$
\text { 3 Op. cit., pp. } 7,8 .
$$


ment of Science, holds its annual meetings in widely scattered cities, thus bringing under its influence a great number of people, whose attention might not be attracted from a distance. Clearly there was still room for an academy chartered by congress and closely related to the national government, to which it might render some such services as the principal countries of Europe receive from their great academies.

Bache's hopes were to be realized twelve years later. On February 11, 1863, Gideon Welles, secretary of the navy, appointed Admiral Davis, Professor Henry and Professor Bache a "Permanent Commission" "to which shall be referred questions of science and art upon which the (navy) department may require information." "4 Encouraged by this governmental recognition, Bache, Peirce, Davis, Gould and Agassiz induced Senator Wilson, of Massachusetts, to introduce in congress a bill to incorporate the National Academy of Sciences. This passed the Senate and House on March 3, 1863 , and was signed by the president on the same day.

${ }_{4}$ Op. cit., p. 1. 
The act of incorporation named fifty men of science as charter members, and limited the membership of the Academy to this number. A second act of congress, passed in 1870 , removed this limitation. At present the amended constitution provides that ten new members may be elected annually. The actual number of names now on the roll is one hundred and thirty-two. In addition to these there are forty-nine foreign associates and one honorary member.

The list of incorporators contains many distinguished names: Agassiz, Alexander, Bache, Barnard, Dana, Davis, Gilliss, Gould, Wolcott Gibbs, Asa Gray, Guyot, James Hall, Henry, Hilgard, Le Conte, Leidy, Lesley, Newberry, Newton, Peirce, Rogers, Rutherfurd, Silliman, Torrey, Whitney, Wyman-among others equally well known. Chosen from the country at large, and fairly representative of the science of the day, the membership was worthy of a truly national body.

The organization of the National Academy was "the first recognition by our government of the importance of abstract science as an essential element of mental and 
material progress." ${ }^{\prime 5}$ One of the objects in the minds of its founders was to confer distinction on men of science who had accomplished important original research, and thus to encourage and stimulate them to further effort. Another prime object was to aid the government in the solution of problems of a scientific nature. In 1863, the year of the Academy's incorporation, the civil war was in progress, and the government stood in need of just such advice as a body of able scientific men could supply. It will be seen later that the assistance of the Academy was often sought and rendered, not alone in this period, but also in subsequent years.

The idea that a democratic government could not consistently confer distinction upon its citizens, though held by some critics of the day, was not shared by Joseph Henry, whose words may again be quoted from the report cited above:

It is not enough for our government to offer encouragement to the direct promotion of the useful arts through the more or less fortunate efforts of

5 From the report for 1867 of Joseph Henry, president of the National Academy, op. cit., p. 14. 
inventors; it is absolutely necessary, if we would advance or even preserve our reputation for true intelligence, that encouragement and facilities should be afforded for devotion to original research in the various branches of human knowledge. In the other countries scientific discovery is stimulated by pensions, by titles of honor and by various social and official distinctions. The French academicians receive an annual salary and are decorated with the insignia of the Legion of Honor. Similar marks of distinction are conferred on the members of the Academy of Berlin and that of St. Petersburg. These modes of stimulation or encouragement may be considered inconsistent with our social ideas and perhaps with our forms of government. There are honors, nevertheless, which in an intelligent democracy have been and may be justly awarded to those who enlarge the field of human thought and human power. Heretofore, but two principal means of distinction have been recognized in this country, viz.: the acquisition of wealth and the possession of political power. The war seems to have offered a third, in bestowing position and renown for successful military achievement. The establishment of this Academy may be perhaps regarded as having opened a fourth avenue for the aspirations of a laudable ambition, which interferes neither with our national prejudices nor our political principles, and which only requires the fostering care of government to become of essential benefit and importance not only 
to this, but all the civilized countries of the world. 6

The special problems raised by the civil war emphasized the value of the services which the Academy might render the government, at a period when most of the scientific bureaus of later years were not yet organized. But the war had only an incidental bearing on the designation of the Academy as the scientific adviser of the nation. The desire of President Lincoln and his Secretary of State to receive advice from the Academy on more general questions is shown by the following letter from Secretary Seward to President Bache : ${ }^{7}$

\section{Department of State, Washington, January 8, 1864.}

Sir: I have the honor to acknowledge the receipt of your note of the 7 th instant, tendering to this department the aid of the Academy of Sciences in any investigation that it may be thought proper to institute with a view to the great reform of producing an uniformity of weights and measures among commercial nations. Be pleased to express to the Academy my sincere thanks for this enlightened and patriotic proceeding, and assure them that, with the authority

6 Op. cit., p. 14.

7 Op. cit., p. 16. 
of the President, I shall be happy to avail myself of the assistance thus tendered to me, and to that end I shall at all times be happy to receive the suggestions of the Academy, or of any committee that may be named by it, in conformity with the spirit of the note you have addressed to me.

I am, Sir, your obedient servant,

William H. Seward

We shall have occasion later to consider how the Academy has assisted the government in the solution of problems of the most diverse character.

The first meeting of the National Academy, attended by more than three fifths of the incorporators, was held at the University of the City of New York on April 22, 1863. Senator Wilson, who had introduced in the senate the bill of incorporation, addressed the Academy at the opening of the first session. After alluding to the fact that the idea of forming such an institution had long existed, he dwelt on the significance of unanimous action by congress at a time when the country was suffering under the burden of the great civil war. With its widely distributed membership, he felt that the Academy would contribute in the future 
toward the unity and indivisibility of the nation.

With Professor Henry in the chair, and other leaders of American science taking part in the deliberations, the work of the Academy was begun under the most favorable auspices. The constitution and bylaws were prepared by a strong committee, including such men as Agassiz, Benjamin Gould, Peirce and Silliman, with Bache as chairman. After three days of discussion they were adopted by the Academy, and finally ratified at the first Washington meeting, held in one of the committee rooms of the senate on January 4-6, 1864.

In the space at our disposal, we must content ourselves with a brief glance at the principal acts of the Academy during the fifty years of its existence, referring the reader to the work so often cited for further details. In accordance with the terms of the constitution, the members were divided into two classes, $(a)$ mathematics and physics, and ( $b$ ) natural history, each class having a chairman and secretary. The names of the sections, and the number of members in each, are given in the following table: 
Class of Mathematics and Physics

Number of

Members

Sect. 1. Mathematics .............6 6

Sect. 2. Physics ...............6 6

Sect. 3. Astronomy, Geography and Geodesy .................. 9

Sect. 4. Mechanies ..............6 6

Sect. 5. Chemistry .............. $3 \quad 30$

Class of Natural History

Number of

Members

Sect. 1. Mineralogy and Geology......6 6

Sect. 2. Zoology .............. 5

Sect. 3. Botany ................ 1

Sect. 4. Anatomy and Physiology ...... 2

Sect. 5. Ethnology ............... 014

Total .......... 44

It is interesting to contrast this organization with that existing at the present time :

Sect. 1. Mathematics and Astronomy...23

Sect. 2. Physics and Engineering.......25

Sect. 3. Chemistry .............23

71

Deduct names counted twice. $5 \quad 66$ 70 
Sect. 4. Geology and Paleontology .....24

Sect. 5. Botany ................. 9

Sect. 6. Zoology and Animal Morphology. 18

Sect. 7. Physiology and Pathology ......15

Sect. 8. Anthropology and Psychology... 9

Deduct names counted twice $9 \quad 66$

Total .......... $\overline{132}$

At the outset, two thirds of the members belonged to the class of mathematics and physics, and only one third to the class of natural history. At present, while the two classes no longer exist as such, it is easy to group the members in the same way. Deducting the names counted twice, we find that 66 would now fall in the first class, and exactly the same number in the second. Thus the discrepancy formerly existing between the two classes has been adjusted in the process of time. ${ }^{8}$

It is important to note that the division of members into sections is solely for the purpose of facilitating nominations for new

8 DeCandolle notes a similar preference for the mathematical and physical sciences on the part of the Berlin Academy during the eighteenth century, which was subsequently adjusted by revision of the statutes. ("Histoire des Sciences et des Savants," 2 ed., p. 261.) 
elections, as now provided by the constitution.

In view of the preponderance of physicists, it is not surprising that three fourths of the scientific papers read at the first Washington meeting were connected with the physical sciences. These papers were referred to the committee on publication, with instructions to publish, but the lack of funds for this purpose stood in the way. When the first volume of the Memoirs finally appeared in 1866, it contained but two of these papers. It was then planned to print the minor papers in the Proceedings of the academy, but this was never done. The first part of the first volume of the Proceedings was published in 1877. This contained the constitution and bylaws, reports on the principal business actions of the Academy, and much miscellaneous matter relating to resolutions passed, titles of papers presented, reports of committees, etc. Publication of the Proceedings was discontinued in 1895, after three parts had appeared. ${ }^{9}$ In 1881, 649 papers had been read at the scientific sessions. President Rogers, feeling that the o Op. cit., p. 44. 
Academy would have received much more recognition from the scientific world if these had been printed, strongly and repeatedly urged that the papers be collected annually and transmitted to congress with the report. ${ }^{10}$ Unfortunately this was never done, and the reports still give only an abstract of the proceedings, in which the papers appear by title. The importance of reviving and enlarging the Proceedings will be discussed in another article.

The Academy has published eleven volumes of Memoirs, containing 68 quarto papers, and seven volumes of Biographical Memoirs of deceased members, in addition to annual reports and reports of committees.

In view of the existence of a detailed history of the Academy, it is quite unnecessary in the present paper to dwell at length upon the events of the first fifty years. A brief outline of the more important work of the Academy is nevertheless essential to clearness, especially in connection with the suggestions for the future which are to be presented later. We may, therefore, consider briefly: (1) the work 10 Op. cit., p. 51. 
of the members; (2) the Academy's work for the national government; (3) medals and trust funds, and (4) cooperation in research.

\section{THE WORK OF THE MEMBERS}

In his report for 1867 as president of the Academy, Joseph Henry spoke as follows of the conditions of membership:

It was implied in the organization of such a body that it should be exclusively composed of men distinguished for original research, and that to be chosen one of its members would be considered a high honor, and consequently a stimulus to scientifie labor, and that no one would be elected into it who had not earned the distinction by actual discoveries enlarging the field of human knowledge. .... since the original organization, the principle before mentioned has been strictly observed, and no one has been admitted except after a full diseussion of his claims and a satisfactory answer to the question, "What has he done to advance science in the line of research which he has especially prosecuted?",

And again, in his valedictory address to the Academy (1878), Henry returned to this subject.

For this purpose great care must be exercised in the selection of its members. It must not be forgotten for a moment that the basis of selection is actual scientific labor in the way of original re- 
search; that is, in making positive additions to the sum of human knowledge, connected with unimpeachable moral character.

It is not social position, popularity, extended authorship or success as an instructor in science, which entitles to membership, but actual new discoveries, nor are these sufficient if the reputation of the candidate is in the slightest degree tainted with injustice or want of truth.

These principles have been observed to the present day, sometimes in the face of great temptation to elect men eminent for achievements other than those of original research. Thus the Academy has counted among its members the large majority of the leaders of American science. While it is of course impossible to describe their individual contributions in these pages, ${ }^{11}$ some remarks on the progress of American research since the foundation of the Academy will be given in a later paper.

THE WORK OF THE ACADEMY FOR THE

\section{NATION}

In the first annual report of the president of the Academy, presented to congress in 1864, Professor Bache remarked:

11 Biographies of the incorporators may be found in the "History of the National Academy," so often cited. 
The want of an institution by which the scientific strength of the country may be brought, from time to time, to the aid of the government in guiding action by the knowledge of scientific principles and experiments, has long been felt by the patriotic scientific men of the United States. No government of Europe has been willing to dispense with a body, under some name, capable of rendering such aid to the government, and in turn of illustrating the country by scientific discovery and by literary culture.

In a previous paper the distinctive position held by European academies as organizations of the government, and the services they render to the state, have been briefly described. ${ }^{12}$ Here, as elsewhere in these papers, we must not overlook the special conditions which distinguish the National Academy from similar bodies abroad. The Royal Society and the Paris Academy of Sciences, dating from the earliest beginnings of science in England and France, have been the media through which the great advances of more than two centuries have reached the world. Discovery after discovery, first presented at their meetings and published in their proceedings, has been rightly associated in the

12 SCIEnCE, November 14, 1913. 
public mind with these great societies, which have fostered science and encouraged the labors of investigators. Thus they have acquired a prestige and a power in the state which could arise in no other way. It is not enough for a nation to charter an organization and to authorize it to act as the adviser of the government in scientific affairs. Appreciation of the fundamental importance of science as the source of all industrial progress, and confidence in the body appointed to advise the nation, are obvious prerequisites to that cooperation between statesmen and men of science which is essential to complete success.

In spite of the disadvantage of a widely scattered membership, whose discoveries and contributions to science have always reached the world through other channels, and with no home of its own to focus attention on its activities, the National Academy has often been called into the service of the country. It will be sufficient to give here a list of the subjects on which the Academy has been consulted by the government, referring the reader to the "History 
of the National Academy" (pp. 201 to 331) for all details.

COMMITTEES APPOINTED BY THE ACADEMY ON BEHALF OF THE GOVERNMENT

1. Committees appointed in accordance with Acts of Congress.

1871. On the Transit of Venus.

1872. On Preparing Instructions for the Polaris Expedition.

1878. On a Plan for Surveying and Mapping the Territories of the United States.

1879. On a National Board of Health.

1894. To Prescribe and Publish Specifications for the Practical Application of the Definitions of the Ampere and Volt. 1908. On the Methods and Expenses of Conducting Scientific Work Under the Government.

2. Committees appointed at the request of Joint

Commissions and Committees of Congress. 1884. On the Signal Service of the Army, the Geological Survey, the Coast and Geodetic Survey, and the Hydrographic Office of the Navy Department.

1902. On the Establishment of a National Forest Reserve in the Southern Appalachians.

3. Committees appointed at the request of the

President of the United States.

1870. On the Protection of Coal Mines from Explosion by Means of Electricity. 
1902. On Scientific Explorations in the Philippines.

4. Committees appointed at the request of the Treasury Department. 1863. On the National Currency (Confidential). 1863. On Weights, Measures and Coinage. 1863. On Saxton's Alcoholometer.

1864. On Materials for the Manufacture of Cent Coins.

1866. On the Prevention of Counterfeiting.

1866. On Spirit Meters.

1866. On Proving and Gauging Distilled Spirits and Preventing Fraud.

1866. On Metric Standards for the States.

1870. On the Effect of Chemicals on Internal Revenue Stamps.

1873. On an International Bureau of Weights and Measures.

1875. On Water-proofing the Fractional Currency.

1875. On Means of distinguishing Calf's Hair from Woolen Goods (Confidential).

1876. On Artificial Coloring of Sugars to Simulate a Lower Grade According to the Standard on which Duties are Levied (Confidential).

1876. On the Use of Polarized Light to Determine the Values of Sugars.

1877. On Demerara Sugars.

1878. On Building Stone to be used for the Custom House at Chicago (no report). 
1882. On the Separation of Methyl Alcohol or Wood Spirits from Ethyl Alcohol.

1882. On Glucose.

1882. On Triangulation Connecting the Atlantic and Pacific Coasts (no report).

1884. On Philosophical and Scientific Apparatus.

1885. On the Tariff Classification of Wools. 1886

and

1887. On the Morphine Content of Opium.

1887. On Quartz Plates used in Saccharimeters for Sugar Determinations.

1890. To Formulate a Plan for a Systematic Search for the North Magnetic Pole.

5. Committees appointed at the request of the Navy

Department.

1863. On Protecting the Bottoms of Iron Vessels.

1863. On Magnetic Deviation in Iron Ships.

1863. On Wind and Current Charts and Sailing Directions.

1864. On the Explosion on the United States Steamer Chenango.

1864. On Experiments on the Expansion of Steam.

1877. On Proposed Changes in the American Ephemeris.

1881. On the Transit of Venus.

1885. On the Astronomical Day, the Solar Eclipse of 1886, and the Erection of a New Naval Observatory. 
6. Committees appointed at the request of the War Department.

1864. On the Question of Tests for the Purity of Whiskey.

1866. On the Preservation of Paint on Army Knapsacks.

1867. On Galvanic Action from Association of Zine and Iron.

1873. On the Exploration of the Yellowstone.

1881. On Questions of Meteorological Science and its Application.

7. Committees appointed at the request of the Department of State.

1866. On the Improvement of Greytown Harbor, Nicaragua.

1903. On the Restoration of the Declaration of Independence.

8. Committees appointed at the request of the Department of Agriculture.

1870. On Silk Culture in the United States.

1881. On Sorghum Sugar.

9. Committees appointed at the request of the Department of the Interior.

1880. On the Restoration of the Declaration of Independence.

1896. On the Inauguration of a Rational Forest Policy for the Forested Lands of the United States.

It will be noticed that many of the questions referred to the Academy are of such a nature that, at the present day, they could be satisfactorily answered by one or 
another of the scientific departments of the government. This probably accounts for the fact that the requests for the Academy's assistance have become less numerous as the national laboratories and scientific bureaus have multiplied and improved. But after full allowance has been made for such wholly desirable developments, it remains true that questions of broad scope, requiring the cooperation of authorities in several fields of knowledge for their solution, must arise from time to time. In such cases the Academy can afford assistance obtainable in no other way, and an enlightened government will advantageously seek its counsel.

The overthrow of the spoils system in national politics will afford the Academy another opportunity to serve the nation. In France, when a professorship in the national university, or the directorship of a national observatory or laboratory falls vacant, the Academy of Sciences is requested to present its first and second choice of a successor. The Minister of Public Instruction then appoints one of the nominees to the position. In the United 
States the need of such counsel is no less urgent than in France.

\section{MEDALS AND TRUST FUNDS}

Election to the National Academy has always been appreciated as a high honor by American men of science. Fortunately, however, the recognition and assistance the Academy has been able to afford to investigators has not been confined to the gift of this mark of distinction. From time to time trust funds have been established, the incomes of which are devoted to the award of medals or to grants for research. The will of Alexander Dallas Bache, first president of the Academy, directed that the residue of his estate, after the death of his wife, should be paid over to the National Academy of Sciences for the "prosecution of researches in Physical and Natural Science by assisting experimentalists and observers." Bache's excellent example has often been followed, with the results shown in the following table.

'The importance of the part played by these funds in advancing science may be illustrated by reference to some of the results obtained. 


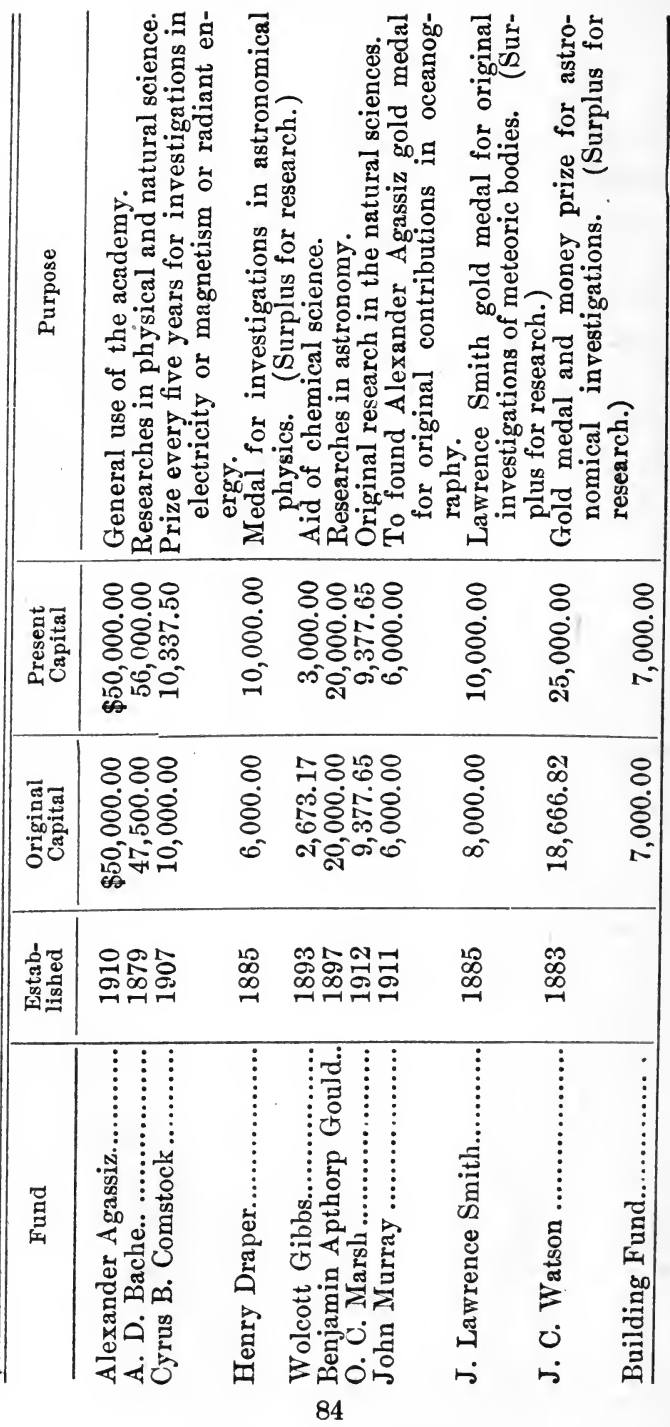


The Agassiz Fund has proved to be of great value in meeting the general expenses of the Academy, for which there was formerly no provision except the dues of the members.

The Bache Fund made twelve appropriations to Hilgard for his magnetic survey of the United States, four to Langley for his important studies of the physical constitution of the sun, six to Wolcott Gibbs for his researches on complex inorganic acids and his studies of the action of chemical compounds upon the animal system, one each to Newcomb and Michelson for their classic determinations of the velocity of light, three others to Michelson for his equally fundamental optical researches, six to Rowland for his great work in mapping and identifying the lines of the solar spectrum, three to Pickering for his pioneer researches in stellar photography, two to Gould for his measurements of the Cordoba photographs of the southern heavens, six to Boss for his studies of solar and stellar motions and his precise measures of standard stars, and two to Osborn for the work of the Academy Committee on Correlation. These cases include only a fraction 
of the total number of grants from the fund.

The Barnard Gold Medal for Meritorious Services to Science, awarded every five years by Columbia University to the nominee of the National Academy, has been given to Rayleigh, Röntgen, Becquerel and Rutherford.

The first award of the Comstock Prize of fifteen hundred dollars was made last April to Professor Robert Millikan, of the University of Chicago, for his researches on the charge of the electron and related investigations.

The Henry Draper Gold Medal for astrophysical research has been awarded to Langley, Pickering, Rowland, Vogel, Keeler, Huggins, Hale, Campbell, Abbot and Deslandres. Several grants to assist investigation have also been made from the surplus income.

The capital of the Wolcott Gibbs Fund for chemical research is being increased by additions of accumulated income, and no grants are being made at present. The income of the Marsh Fund is also being added to the capital.

A large number of investigations have 86 
been assisted by the Gould Fund, including those of Doolittle, Parkhurst, Yendell, Newcomb, Leavenworth, Comstock and others. At present the income is used mainly for the support of the Astronomical Journal.

The Alexander Agassiz Gold Medal, established by Sir John Murray for oceanographic research, was awarded for the first time last April to Dr. Johan Hjort, of the Norwegian Fish Commission, for his valuable contributions to knowledge relating to deep-sea life.

The Lawrence Smith Gold Medal for the investigation of meteoric bodies has been awarded but once, to H. A. Newton, of Yale, for his researches on the orbits of meteors. Appropriations from the fund have supplied Yale University with apparatus for the photography of meteors, and provided for the publication of a catalogue of meteorites, for their chemical analysis and for the study of their luminous trains.

The Watson Fund has aided the important work of Chandler on the variation of latitude, and that of Comstock on the constant of aberration, in addition to many other important grants. Since 1901 the 
income has been very effectively used by Leuschner in the computation of the perturbations of the asteroids discovered by Watson. The Watson Gold Medal, with one hundred dollars in gold, has been awarded to Gould, Schönfeld, Auwers, Chandler, Gill and Kapteyn for their astronomical investigations.

In view of its national charter, the high plane of its membership, and its special advantages as the representative of the United States in the International Association of Academies, the National Academy is most favorably qualified for the custody and efficient use of trust funds. Appreciation of this fact, amply indicated by the above list of gifts and bequests, should grow with the reputation of the Academy. It is safe to predict that the privilege of securing the Academy's aid in the control and disbursement of large sums for the benefit of science will be widely sought in the future. In this connection attention should be called to the present lack of medals and funds especially devoted to the recognition and aid of researches in mathematics, engineering, geology and va- 
rious departments of biology and anthropology.

COOPERATION IN RESEARCH

As an agent for the furtherance of cooperative research, the National Academy occupies a unique position among American societies. In these days of far-reaching investigations, involving the common action of men of science distributed throughout the world, the great majority of cooperative projects are international in character. Here the peculiar advantage of the Academy appears. The International Association of Academies is made up of the national academies of sixteen countries. Each academy is pledged to support only such cooperative undertakings as are endorsed by the association. Thus the constituent members of this body, through their delegates at its triennial meetings, are most favorably placed for the initiation and furtherance of such international movements.

As an illustration of the work already undertaken by the National Academy in this field, mention may be made of the International Union for Cooperation in Solar Research. In 1904, the Academy, 
through its Committee on Solar Research, invited various academies, physical and astronomical societies, and other organizations interested in the subject, to send delegates to a conference, with a view to the initiation of international cooperation in this field. Meetings have since been held at Oxford in 1905, Paris in 1907, Mount Wilson in 1910 and Bonn in 1913. The constituent societies, each of which is represented in the Union by a standing committee, are as follows:

The Royal Society of London, the Academies of Amsterdam, Barcelona, Berlin, Paris, St. Petersburg, Stockholm and Vienna, the Swiss Society of Natural Sciences, the Astronomical Societies of London, America, France and Canada, the Physical Societies of Berlin, Italy, Spain, France and America, the Society of Italian Spectroscopists, the Solar Physics Committee, the Solar Sub-committee of the International Meteorological Committee and the National Academy of Sciences.

The standards of wave-length which are being established by the Union, as the result of extensive cooperative studies, will be used universally by spectroscopists. International committees, appointed by the 
Solar Union, are studying the solar rotation, the spectra of sun-spots and the intensity of the solar radiation, on a common plan. Spectroheliographs are also in use, for the almost continuous photography of the sun, at the observatories of Kodaikanal, India; Catania, Sicily; Potsdam, Germany; Meudon, France; Tortosa, Spain; Cambridge, England; Williams Bay, Wisconsin; Tacubaya, Mexico; and Mount Wilson, California.

A new solar observatory, which is about to be established in New Zealand through the generosity of Mr. Thomas Cawthron, will fill the gap in longitude between California and India, and thus aid in keeping the rapidly changing phenomena of the solar atmosphere constantly under observation. At the Mount Wilson meeting of the Union, it was decided to enlarge its scope so as to include the whole range of astrophysics, and a representative committee was appointed to report on the classification of stellar spectra. It is now evident that the Solar Union is destined to play an increasingly important part in the field of international research.

The Solar Union is one of the organizations endorsed by the International As- 
sociation of Academies, to which it makes regular reports. Another of the international investigations conducted under the auspices of the association is that of the Brain Commission, the American Committee of which is also closely related to the National Academy.

The Committee on International Paleontologic Correlation, appointed by the Academy in 1908, has recently completed its work. Aided by the Bache Fund, the eommittee has pushed forward the important work of correlating the geologic formations of Europe and America on the basis of their paleontologic contents. The results have been published in a series of papers, by members of the committee, most of which treat of the mammals of the tertiary epoch and the formations which contain them in North America. Marsh and Cope dealt with the formation of the American Eocene as units, even when their thickness ranged from 1,000 to 2,000 feet. These formational units have now been split up into sub-units, or life zones, usually distinguished by geologic discontinuity. At the same time there has been a marked increase in the precision of recording the succession of species in certain 
formations which contain several levels of life zones, thus permitting exact comparisons with other life zones to be instituted. The importance of such work is obvious in connection with the trend and rate of development in different parts of the world, the possibility of geographic intercourse at certain epochs, and the cycles of physiographic and climatic change.

It is thus evident that the Academy is in a most favorable position to extend its operations in the field of international research, where the advantages of its national and representative character are felt to the full, and the disadvantages of its scattered membership are of minor importance.

From this brief survey it appears that the National Academy of Sciences, in spite of many obstacles, has played an important part in the development of American science. The time is now favorable for an extension of its work into new fields, which must be occupied if the special opportunities and obligations implied by the Academy's national charter are to be fully realized. In a later article some of the possibilities of future progress will be considered. 
III. THE FUTURE OF THE NATIONAL ACADEMY OF

\section{SCIENCES ${ }^{1}$}

IN previous papers of this series ${ }^{2}$ we have traced the development of European academies and observed the powerful influence they have exercised on the advancement of research; we have watched the beginnings of scientific investigation in the

1 This paper was presented at the Baltimore meeting of the National Academy in November, 1913. By action of the council, a manuscript copy was subsequently sent by the home secretary to each member of the academy for criticism and comment. In preparing the paper for publication, the author has had the advantage of seeing these replies. Except for a few minor verbal changes, the text is printed in its original form, with the addition of new paragraphs in square brackets.

2 I. "'The Work of European Academies," ScIEnCE, 38, 681, 1913. II. "The First Half Century of the National Academy of Sciences," SCIENCE, '39, 189, 1914. 
United States, and their public recognition by act of Congress establishing the National Academy of Sciences; and we have followed the history of the Academy during the half century which has elapsed since its origin. In view of the great part which academies have played in the past, and the fact that the rapid development of original research in this country has carried us out of the pioneer period, the National Academy now faces an exceptional opportunity to impress its influence upon the future scientific work of the United States. But if it enjoys an opportunity, it also faces a duty, imposed upon it by its national charter and by its position as the sole representative of America in the International Association of Academies. The history of the Academy shows that it has taken its obligations seriously, by complying with requests from the executive and legislative departments of the government for advice on scientific matters, by the use of trust funds for the advancement of research, by the award of prizes and grants for investigation, by the initiation and support of international cooperation in research, and by such other 
means as its limited endowment has permitted. But while the rapid growth of the scientific bureaus of the government has reduced the number of questions which would otherwise be submitted to the Academy, the enormous increase in the wealth of the country, and the expansion of its trade relations have raised new problems and advanced new opportunities. These developments, which have resulted in the multiplication of universities, observatories and laboratories, and the foundation of great endowments for research, place the Academy in a new position, and impose the question whether it can not now accomplish much more than was formerly possible. It is the purpose of this paper to open the discussion of this question, in the hope that its further consideration by other members may lead to an extension of the work and usefulness of the Academy.

Fortunately we may take advantage of the rich store of experience accumulated by the European academies during their long histories. In seeking to adapt this to our own needs, we must of course recognize the special conditions existing in the United States. The great area over which our 
members are distributed and the lack of any such centralization as we see in London or in Paris, will always stand in the way of weekly meetings like those of the Royal Society and the Paris Academy. But if we can not hope to see our leading investigators personally demonstrate each step in their progress before academic audiences, as Faraday and Pasteur and many another have done abroad, we can nevertheless provide for lectures and papers illustrated by experiments in connection with the semi-annual meetings of the Academy, and possibly for others of a public character, extending throughout the year, after the manner of the Royal Institution of London. The disadvantage of our members in being unable to read accounts of their latest advances before weekly meetings of their colleagues can also be largely offset by the publication of Proceedings, in which the first results of all new work may be adequately presented. Thus, though we lack some of the advantages of centralization, these may be largely overcome, while retaining the very great advantage of a widely distributed membership 
representing the scientific interests of every section of the country.

FUNCTIONS OF A NATIONAL ACADEMY

The criticism has sometimes been directed against academies covering the whole range of knowledge that their place has been sufficiently filled by the special societies devoted to particular branches of science. For more than a century the Royal Society and the Paris Academy served all the purposes of science in Great Britain and France, but toward the end of the eighteenth century special societies began to develop in England. The establishment of the Linnean Society in 1788 did not appear to give special concern to the members of the Royal Society. But when the Geological Society was instituted in 1807, Sir Joseph Banks, then President of the Royal Society, united with Sir Humphry Davy and others in a strenuous attempt to amalgamate it with the parent body. The Royal Astronomical Society was established in 1820 , partly as the result of the accumulation of valuable observations too extensive for the Royal Society to publish. Sir Joseph, though he had himself aided in the 98 
establishment of the Linnean Society, was greatly perturbed at this further development. A short time later he died in the belief that the special societies had struck a severe blow at the respectability and usefulness of the Royal Society, by robbing it of many of its members and laying claim to some of its most important departments. ${ }^{3}$ But his fears were wholly unwarranted, and the special societies continued to grow and multiply, to the advantage of science and of the Royal Society itself. Their extensive publications have not detracted from the volume or the quality of the Philosophical Transactions and the Proceedings, and each of these societies, by contributing to the development of some special field, has helped to build up that great organization of British science of which the Royal Society is the acknowledged and venerated head. These details will not be out of place if they help to emphasize a principle which should always be respected in the work of the National Academy. The societies and journals which have been established to

3 Barrow, "Sketches of the Royal Society," pp. 10, 256; Weld, "History of the Royal Society," pp. 242, 246. 
meet the needs of scientific progress have come to stay. It is neither necessary nor in any way desirable to usurp their functions, which are the result of a natural process of evolution. There is ample room, however, for academies devoted to the whole range of science. The rapid advance of research in a thousand ramifying fields has left much intermediate territory unexplored. The approach to these undeveloped regions may be made from more than one direction, and through the aid of more than one method. Thus nothing can be more stimulating to the progress of research than an acquaintance with the investigations and processes which are constantly being developed in fields other than one's own. Mathematics has received its principal impulses from astronomy and physics. Physical chemistry is indebted, on the one hand, to Pfeffer the botanist for the study of vegetable cells, and on the other to the mathematical and physical investigations of Willard Gibbs, Van der Waals and Arrhenius. Astrophysics came into existence through the use in astronomy of the spectroscope and other physical instruments. Every department of science 
sheds a luster which should illuminate, not only its particular territories, but others, near and far, occupied by other workers. The importance of recognizing and utilizing this fact must therefore increase as time goes on.

[It has been truly said that an academy can hope to accomplish large results only as it succeeds in meeting the conditions of the present rather than those of the past. What are existing conditions in science? Surely none is more striking than the contraction of the field of the average investigator. Specialization is inevitable in the maze of modern progress, and the narrowing effect of constant devotion to a single subject must become still more apparent as science ramifies further. A general academy, by insisting on the importance of large relationships, by demonstrating the unity of knowledge, by recognizing the fact that fundamental methods of research, wherever developed, are likely to be applicable in more than one department, can do much to broaden and to stimulate its members. The correlation of research should be counted as one of its prime objects, and 
its energies should be largely directed to this important end.]

We are thus led to the conclusion that the functions of a National Academy should be of the broadest character, and that the advantage of sharing in the results of all its departments should belong to every member. Thus the policy of our National Academy of avoiding division into separate sections, ${ }^{4}$ and of bringing papers on the most diverse subjects before the entire body, is fundamentally sound and should be maintained. Later in this paper the question will be considered whether the range of the Academy's activities should be extended so as to give increased recognition to departments of knowledge other than the physical and natural sciences.

Under the conditions now existing in the United States, there is reason to believe that the functions of the National Academy might well be multiplied so as to meet a wide variety of needs. It should stand, first of all, as a leading source and supporter of original research and as the national representative of the great body of American investigators in science. To the

4 Except for voting purposes. 
government it should make itself necessary by the high standard of its work, the broad - range of its endeavors, and the sane and scientific spirit underlying all of its actions. To its members it should offer stimulus and encouragement in their investigations; due recognition of their advances; financial assistance and the use of instruments at critical periods in their work; the advantage of listening to papers ranging over the whole field of science, bearing suggestions of principles or methods likely to develop new ideas; contact with the greatest leaders of research from all countries and opportunities to listen to descriptions of their work; access to books and manuscripts not easily obtainable from other sources; and participation in international cooperative projects in every field of investigation. In the public mind it should rank as the national exponent of science, and as the agency best qualified to bring forward and illustrate the latest advances of its own members and of the scientific world at large. To representatives of manufactures and industries, the Academy should serve to promote the appreciation and widespread use of the scientific principles and methods 
which have built up the great industrial prosperity of Germany. With other societies devoted to various branches of science, it should cooperate in harmony with the best interests of American research. Toward local bodies for the encouragement of investigation and the diffusion of knowledge, it should act as an inspiring example and a reliable source of support. And in the broad field of international cooperation, it should unite with the leading academies of the world in the endeavor to perfect the organization of research and in the use of all agencies contributing to its advancement.

\section{NEEDS OF THE ACADEMY}

Many of these objects have been accomplished by the National Academy in the past, but others remain for the future. The greatest aid in accomplishing its full work would be met by the provision of a suitable academy building, and an endowment sufficient to publish Proceedings, conduct research, provide public lectures, maintain exhibits illustrating current investigations, and to meet such additional needs as are implied by the Academy's national charter 
and its obligations to the scientific world and the general public. Through the courtesy of the Smithsonian Institution, extended in the year of the academy's organization, the annual meetings are held in the National Museum, in rooms ordinarily employed for other purposes. Thus the Academy does not even possess a permanent office, or a room for its library, which will be needed in the future for its work of research. It has therefore been compelled from the outset to decline many offers of books, and thus a large and valuable collection, comprising publications offered by many of the great academies, laboratories and observatories of the world, has been lost. ${ }^{5}$

It is difficult to overestimate the value of a suitable building in commanding public appreciation and support for any institution. Visible evidence of the Academy's existence is a matter of no small importance, when it is remembered that the average American citizen, though wellacquainted with the name of the Paris

5 The Academy has accepted some gifts of books, which are packed away (unbound) in the storerooms of the Smithsonian Institution. 
Academy through press reports of discoveries announced there, has never heard of our own national organization. But a building used as a storehouse and occupied but once a year is not enough. The Academy must be known as a living and active body, which recognizes and fulfills its many duties to science and the public. If its headquarters were constantly employed for such purposes as are enumerated later, the Academy would soon be looked upon as the natural source of information regarding the latest developments of science, and more generally recognized as the national representative of American research.

IMPORTANCE OF PUBLISHING PROCEEDINGS

As explained in a previous paper, the name of the National Academy has never been associated with the work of its members, since the papers read at its meetings have not been published by the Academy. Thus it has not been sufficiently identified with the progress of American research, and the chief source of the reputation of the Paris Academy and the Royal Society has been lacking. But though the Academy 
would become more widely known by the publication of Proceedings, it would be foolish to take such a step merely to accomplish this purpose. The establishment of a new journal, in these days when the literature of science has become exceedingly complex, should never be undertaken without serious consideration of its probable usefulness. If it fulfills no good and lasting purpose, its life will be deservedly short. Hence we may not imitate the example of societies which established their publications before the special journals had taken the field. We must recognize, on the one hand, that the various journals devoted to particular branches of science meet a clearly defined need and should not be rivaled, even to the apparent advantage of the Academy. On the other hand, we must also remember that the members of the Academy have adopted a regular plan of publication, the interruption of which might interfere with the accessibility of their papers. Thus, if Proceedings are to be established, they should be so planned as to serve a useful scientific end and be distinctly advantageous, not merely to the Academy itself, but to all of its members. 
I am strongly of the opinion that no step which can be taken at the present time would be so beneficial to the National Academy as the publication of Proceedings containing the first announcements of important advances and the chief results of American research. I believe, furthermore, that this can be done in such a way as to benefit the members and contribute to the advancement of science. In many departments of the Academy's work papers published in the special American journals of limited foreign circulation do not reach a sufficiently large group of European readers. I am told that this is particularly true in biology, where American investigators are producing a great body of results of the first importance. Thus the Proceedings of the Academy, if properly distributed, might be made to serve the very useful purpose of bringing the work of a large number of investigators to the attention of scholars abroad. But in order to preserve all interests, and to interfere in the least degree with present plans of publication, the Proceedings should not be designed to occupy such a place as the special journals adequately fill. 
[The chief advantage of the Proceedings would not be the same in all departments of science. In mathematics, where the existing journals are greatly overcrowded, prompt publication of the condensed results of new research would be heartily welcomed. The same thing is true in botany and in many other subjects. In fact, improved means of prompt publication would be generally appreciated by Academy members. In biology, as already remarked, the great number of special journals prevents many of them from reaching European laboratories, where American research is frequently overlooked as a consequence. In astronomy and astrophysics, which have fewer journals, the circulation of the chief American journals is large, and their contents reach all astronomers abroad. But the practise of publishing separate series of circulars or bulletins, which has been adopted by many American observatories, confines the circulation of their papers to the limited number of astronomers and observatories on their mailing lists. If brief accounts of the broader aspects of these investigations were printed by the Academy, they would be useful to astronomers making 
a general survey of progress in their own field. But they would be even more serviceable to the mathematician, physicist, meteorologist, chemist, geologist or other investigator who may find information of direct or suggestive value in the results of astronomical research. Conversely, even those astronomers who keep in touch with progress in mathematics or physics can not also examine the numerous journals of chemistry, geology and other subjects which contain results applicable in their own work. It will thus be seen that the Academy could perform an important service in its special province of correlating knowledge by publishing papers covering the whole range of science.

'The value of the Proceedings in strengthening the position of American science at home and abroad should not be overlooked. The rapid progress of American research in a single field may be known to the European specialist, but he may not realize that similar advances in other departments have raised American science to a new level. Recognition of this fact is desirable, not for the gratification of national pride, but because the international influence of 
America in science will grow with its prestige. The combination of effort which the Proceedings would represent, and the demonstration they would afford of American activity in research, are factors of real significance in securing that recognition and standing, both at home and abroad, which is needed to accelerate future progress.]

To accomplish the desired result, it would seem that the Proceedings should be intermediate in character between the Comptes Rendus of the Paris Academy and the Proceedings of the Royal Society. Papers read before the Paris Academy on Monday are printed and issued in the Comptes Rendus on the following Saturday-a record for speed which we should not expect to rival. Such accelerated publication, while it doubtless possesses certain advantages, renders impossible that more leisurely editorial examination which most journals demand. The Proceedings of the Royal Society, on the other hand, appear at irregular intervals, and frequently contain long and detailed papers, which with us might better find a place in the special journals. In the case of the National Academy it is 
doubtful whether publication at shorter intervals than one month is necessary, but the possible advantages of fortnightly publication should be carefully considered.

It goes without saying that papers for the Proceedings, while comparatively brief (perhaps averaging from three to five pages), should not be hasty announcements based on inadequate data. On the contrary, the dignity of the National Academy and the best interests of its members demand that only carefully matured conclusions, resulting from prolonged observational or theoretical research, should appear under the Academy's imprint. Measures and other exact data needed to establish these conclusions would be a necessary part of such papers, though long numerical tables, profuse illustrations, and detailed accounts of minor topics should be reserved for publication in the special journals, to which members would continue to contribute as before. The Academy Proceedings would thus serve for the first announcement of discoveries and of the more important contributions to research, illustrated by line cuts and occasional halftones in the text, when essential to clearness, but free from 
unnecessary detail and extensive numerical data. Non-members, as well as members, should be invited to contribute, with the understanding that their papers are to be presented by a member of the Academy, as in the case of the Paris Academy and the Royal Society. ${ }^{6}$

The constitution of the National Academy already provides for the issue of Proceedings, as well as Memoirs and Annual Reports. In fact, as explained in a previous paper, three numbers of Proceedings were published, though they did not contain papers presented to the Academy. There is

6 The Proceedings should be so planned as to interfere in the least possible degree with the Journal of the Washington Academy of Sciences, which is a publication similar in character to the one here proposed. As the Journal is devoted mainly to work done in Washington, or presented before the various Washington societies (other than the National Academy), no important overlapping of the two publications need be anticipated, especially as members of this Academy have rarely contributed to the Journal.

7 [The Academy voted, at its meeting of November, 1913, to begin the publication of Proceedings as soon as arrangements could be perfected. The first number will appear in January, 1915.] 
therefore no need of any radical departure requiring amendment of the constitution. In other words, if sufficient funds are available, this very important step toward the development of the Academy can be taken by simple affirmative vote. ${ }^{7}$

The annual volumes of the Proceedings, bringing together for the first time the best product of American research, would place the Academy in a clearer light before the academic world. Annual Reports and infrequent volumes of Memoirs receive scant attention, except from a few specialists, in the libraries of our contemporary societies. But the Proceedings, published at regular intervals, and containing a standing notice of the Academy's publications, would aid in making them better known. The quarto Memoirs, eleven volumes of which have already appeared, afford an excellent place for extended publication, when the necessity for lengthy tables, numerous plates, or long discussions of data places the manuscript beyond the reach of the special journals. The publication of the Proceedings might serve to disclose much material worthy of use in the $\mathbf{M e}$ moirs, and the editorial board should be 
constantly on the watch for opportunities to extend the Memoirs and to render them more serviceable to science.

\section{SCIENCE AND THE PUBLIC}

The circulation of the Proceedings would necessarily be limited to scholars and scholarly institutions-they could not be expected to reach the general public. Here a difficulty remains to be overcome, since the results of original investigations should certainly be made more generally known and more clearly understood than they are at the present time. The average man of science, after sad experience with the daily press, is usually forced to the conclusion that newspaper publication is synonymous with rank sensationalism. Repeatedly told, and not without justice, that his cloistered wisdom should reach a wider world, he sometimes yields to the persistent demands of a reporter. The outcome is too well known to require telling. Even in the case of a really intelligent and conscientious reporter, who does not distort or exaggerate, the "headline man" may be depended upon to provide a grotesque disguise. A few experiences of this sort suffice for most 
investigators. They are soon forced to shut out the reporter, and are well pleased when they succeed. Yet they recognize that the exclusion of the public from all contact with their work is neither fair nor desirable. Some way should be found of bridging the gap.

A plan followed in England by the Royal Society, of circulating brief abstracts on the day when a paper is read, which are afterwards published in Nature (sometimes in condensed form), is one which we might advantageously imitate. When a paper is accepted by the editorial board for publication in the Proceedings, a brief abstract, preferably prepared by the author, should be sent to ScIEnce (and perhaps also to Nature). At the same time this abstract, or a briefer one in less technical language, might be communicated to the Associated Press. It goes without saying that papers for the Proceedings would differ widely in their availability for popular treatment. Probably only a comparatively small proportion of them would contain results suitable for use by the Associated Press, but all would doubtless be published in abstract by ScIEnce. 
Through the Associated Press, and also through certain conservative newspapers and magazines, the Academy could thus bring before the public the actual results of scientific research, as distinguished from the false and distorted conceptions of science which most of our newspapers now disseminate.

\section{LECTURES ON RESEARCH}

The plan of publication outlined above is but one of several methods by which the Academy may enlarge its usefulness. Public lectures should also be instituted, primarily for the benefit of the Academy members, but also with the expectation of reaching a larger circle. Here the Academy would do well to study and imitate the Royal Institution of London, where original research and the diffusion of knowledge are combined in a very effective manner. In brilliant addresses, illustrated by lantern slides and experiments, a long line of illustrious speakers, best typified by Faraday, have charmed and enlightened the most distinguished audiences. Many of these speakers, including Davy, Faraday, Tyndall, Dewar, Rayleigh and Thomson, 
have been drawn from the staff of the Royal Institution. But their English contemporaries, as well as scientific men from all parts of Europe and the United States, have also been invited to describe their latest advances. The speaker at a "Friday Evening Discourse" is faced by the leaders of English thought and action in many fields. Privileged to select from the large collection of historic instruments accumulated during a century, and even to illustrate his points with the apparatus of Faraday himself, he feels an inspiration that no other platform affords. In such an atmosphere he learns to appreciate the dignity of popular science at its best, and to perceive how the busiest and most successful of present-day physicists can find time to deliver elaborate courses of Christmas lectures to a juvenile audience. These lectures, instituted by Faraday, are now in their eighty-seventh season. Under such topics as "The Chemistry of Flame" they have afforded him and his followers an opportunity to show how simply and beautifully the principles of science can be made to appeal even to young children. ${ }^{8}$ The 8 The last course of Christmas Juvenile Lec118 
art of the popular lecture should be developed in the United States by the National Academy. Under its auspices, and with the example of the Royal Institution behind him, the lecturer need not fear for his dignity. The Academy would soon find its reward in the increasing appreciation of its work and purposes, the spread of scientific knowledge, and ultimately in larger endowments for research.

As a first step in this direction, the children of the late William Ellery Hale have established a course of lectures in memory of their father. Their object in doing so is twofold. In the first place, it is hoped that the lectures may add to the attractiveness of the Academy meetings, both to the members and the public. Again, it is believed that by a suitable choice of lecturers and topics, the inter-relationship of the various fields of research represented in the Academy, and the light thrown by the methods of investigation or of interpretation employed in one field upon those of another, may be illustrated in an effective tures, on "Alchemy," “Atoms," “Light," "Clouds," "Meteorites"' and "Frozen Worlds," was given by Sir James Dewar. 
way. Moreover, the lectures will afford an opportunity of testing whether the Academy may not further assist in increasing public appreciation of the cultural and the industrial value of science.

\section{SCIENCE IN EDUCATION}

In the Academy of Plato and the Alexandrian Museum the functions of an academy and a university were united, and the work of instruction went hand in hand with the development of new knowledge. The growth of the modern university has now removed from national academies their former work of teaching a body of students, but their opportunity to exert a favorable influence on the educational methods of the nation remains. The Institute of France, as planned by Talleyrand and Condorcet, ${ }^{9}$ was to control public instruction and offer courses to advanced students. This was not carried out, but an instance of the same sort is afforded by the Academy of Munich, which has charge of the public instruction of Bavaria.

9 See Hippeau, “L'instruction publique en France pendant la révolution," Vol. 1, pp. 115, 228. 
There is no apparent reason why our own National Academy should have a formal connection with educational institutions. But in harmony with its purpose to advance knowledge in the United States, it should contribute toward the development of the science of education and take advantage of the possibility of increasing public appreciation of the educational value of science.

In a presidential address which excited great public interest in England, Sir William Huggins emphasized before the Royal Society the importance of science in education. ${ }^{10}$ We need not dwell upon his arguments regarding the value of scientific training in developing the power of accurate observation and the habit of correct and cautious reasoning. But a more neglected phase of science in educationits power of awakening and expanding the imaginative faculty-may be referred to in his own words:

Surely the master-creations of poetry, music, sculpture and painting, alike in mystery and grandeur, can not surpass the natural epics and scenes of the heavens above and of the earth beneath, in their power of firing the imagination, 10 Huggins, "The Royal Society," p. 109. 
which indeed has taken its most daring and enduring flights under the earlier and simpler conditions of human life, when men lived in closer contact with Nature, and in greater quiet, free from the deadening rush of modern society. Of supreme value is the exercise of the imagination, that lofty faculty of creating and weaving imagery in the mind, and of giving subjective reality to its own creations, which is the source of the initial impulses to human progress and development, to all inspiration in the arts, and to discovery in science.

Of all the teachings of science, the principle of evolution makes by far the strongest appeal to the imagination. Isolated phenomena, however remarkable, acquire a new meaning when seen in its light. Minute details of structure in animals or plants, slight differences of the relative intensity of lines in the spectra of stars, may become of intense interest even to the elementary student if explained as steps in a great process of development. But after all that has been said and written since the time of Darwin, we fail to take full advantage of our opportunity. Properly presented, a picture of evolution in its broadest aspects would serve better than any other agency to stimulate the imagination, 
to awaken interest in science, and to demonstrate that its cultural value is in no wise inferior to that of the humanities. To the average student, even physics and chemistry are distinct branches of science, each occupied with its own problems. Astronomy, he knows, concerns itself with the heavenly bodies, botany with plants, zoology with animals. But if he studies these subjects at all, he almost invariably fails to realize their relationship, because no binding principle, like that of evolution, is brought prominently to his attention or, at the best, is restricted in its application to some single organic or inorganic field.

When Humboldt wrote "Cosmos" and Huxley lectured on "A Piece of Chalk" and other subjects, they showed what might be accomplished in picturing the problems of science in a broad way. The National Academy is better qualified than any other body in America to demonstrate what can be done in the same direction with the rich store of knowledge acquired since their time. A course of lectures on evolution, beginning with an account of the constitution of matter, the transformation of the elements, and the electron theory; picturing the heav- 
enly bodies and the structure of the universe, the evolution of stars and planets, and the origin of the earth; outlining the various stages of the earth's history, the formation and changes of its surface features, the beginning and development of plant and animal life; explaining modern biological problems, the study of variation and mutation, and the various theories of organic evolution; summarizing our knowledge of earliest man, his first differentiation from anthropoid ancestors, and the crude origins of civilization; and connecting with our own day by an account of early Oriental peoples, the rise of the Egyptian dynasties, and their influence on modern progress: such a course, free from technicalities and unnecessary details, richly illustrated by lantern slides and experiments, and woven together into a clear and homogeneous whole, would serve to give the average student a far broader view of evolution than he now obtains, and leave no doubt in the hearer's mind as to the cultural and imaginative value of science.

The William Ellery Hale lectures will open with a series on evolution, so designed as to be of interest to members of the Acad- 
emy, and at the same time to be intelligible and attractive to the public. At each meeting two lectures will be given by a distinguished European or American investigator, chosen because of his competence to deal with some branch of the subject. The first course of lectures, to be given by Sir Ernest Rutherford at the annual meeting in April, 1914, will deal with the constitution of matter and the evolution of the elements. ${ }^{11}$ At the conclusion of this series, which will extend through several years, it is hoped that the lectures may be brought together, in a homogeneous and perhaps somewhat simplified form, into a small volume suitable for use in schools.

The course above outlined will serve to test the question whether the Academy may advantageously enter more extensively into the lecture field. So far as the members of the Academy are concerned, it seems probable that lectures by able American and European investigators would add to the interest of the meetings. But the value of

11 [The second course was given at the autumn meeting by Dr. William Wallace Campbell on "Stellar Evolution and the Formation of the Earth."] 
the lectures to the general public can only be determined by experiment. If a suitable building can be obtained, and the success of these lectures is sufficient to warrant it, the foremost investigators, American and foreign, might be invited from time to time throughout the year to describe and illustrate their advances in the lecture-hall of the Academy. This plan is already followed by various American institutions, but the Academy, because of its national character, would be better able to attract the best men and to give their lectures more than local significance. Ample facilities for experimental illustration would also go far toward enhancing the value of the lectures. In short, the example of the Royal Institution should be followed as closely as possible. ${ }^{12}$

\section{INDUSTRIAL RESEARCH}

The value of science to the American manufacturer, though no new theme, is capable of wide development at the hands of the National Academy. In a presidential

12 [It has been suggested by several members that these lectures might be repeated in two or three large cities, in cooperation with local scientific institutions.] 
address delivered before the Royal Society in 1902, Sir William Huggins dwelt on the "Supreme Importance of Science to the Industries of the Country, which can be secured only through making Science an Essential Part of all Education." He saw the fruits of English discoveries passing into the hands of Germany, whose universities have so long fostered and spread abroad the spirit of research, and wondered at the apathy of the average British manufacturer toward scientific methods. Huggins, speaking in plain language, pointed to the chief source of weakness"the too close adherence of our older universities, and through them of our public schools, and all other schools in the country downward, to the traditional methods of teaching of medieval times."

In this country, where the classics do not dominate the university system, the task of arousing an adequate appreciation of the enormous benefits which science can render is a far easier one. We must have, first of all, a widespread interest in science and some comprehension of its problems and methods. A general 13 "The Royal Society," p. 29. 
course on evolution, given to all college students, should be of great service as an entering wedge. More students might thus be led to take science courses, while those who specialize in the humanities could gain a better conception of what science means. The rapid development of research in our universities and technical schools promises to influence the faculties of our colleges, where a man's success as a teacher will be materially enhanced if he is also a producer of new knowledge. Thus the future is promising in the educational field.

On the side of our manufacturers, who are eager to adopt the most efficient methods, the outlook is equally favorable, as President Little of the American Chemical Society showed so effectively in his address on "Industrial Research in America." 14 Many great firms are establishing large research laboratories, where problems of all kinds are under investigation. The development within the past few years of Taylor's efficiency system is another indication that the advantages of scientific methods are being grasped and applied in the arts. But the opportunities in this direction are almost 14 SCIENCE, 38, pp. 643-656, 1913. 
endless, and the National Academy would do well to devise ways and means of convincing not only the large manufacturers, but the small manufacturers as well, of the industrial importance of scientific research. Lectures on recent advances in engineering, by European and American leaders, should have a powerful influence if carefully planned and effectively illustrated. Parsons on the steam turbine, ${ }^{15}$ Marconi on wireless telegraphy, ${ }^{15}$ Goethals on the Panama Canal, would attract large audiences and appeal in published form to a wide public.

But while the advantages resulting from ingenuity and invention and the best practise of engineering should certainly be brought out in the course of lectures I now have in mind, the improvement of manufactured products by research methods, and the potential industrial value of pure science are the points which should be emphasized. We have a long way to go before any single manufacturing firm employs seven hundred qualified chemists, as the combined chemical factories of Elberfeld, Ludwigshafen and Treptow do. The su15 Lectures before the Royal Institution, 1911. 
premacy in this field of Germany, which produced chemicals valued at $\$ 3,750,000,000$ in 1907 , is directly due to the carefully directed research of an army of chemists, who learned the methods of investigation in the universities and technical schools. ${ }^{16}$ The Berlin Academy of Sciences has also contributed in an important way to this result, through van't Hoff's investigations of the Stassfurth salt deposits. The recent rapid development of our own chemical industries leads us to hope that similar advances may soon be achieved in the United States. In electrical engineering, at least, we are already making comparable progress.

But the average man of business is much better able to appreciate the value of research directly applied to the improvement of manufactures than to comprehend the more fundamental importance of pure science. We must show how the investigations of Faraday, pursued for the pure love of truth and apparently of no commercial

16 In 1910 the Nobel prize for chemistry went to Germany for the sixth time, thus giving to a single country sixty per cent. of all the Nobel prizes for chemistry awarded up to that date. 
value, nevertheless laid the foundations of electrical engineering. If we can disseminate such knowledge, which is capable of the easiest demonstration and the most striking illustration, we can multiply the friends of pure science and secure new and larger endowments for physics, chemistry and other fundamental subjects.

[While there can be no doubt of the importance of emphasizing the value of industrial research, the necessity of vigilance in the interests of pure science is shown by the opposite tendency of several recent writers, who measure science solely in terms of its applicability in the arts.

The stimulus of commercial rivalry is doubtless a factor in the rapid progress of our great industrial laboratories, but I doubt if their directors would maintain that all chemical research should be of the industrial kind. Immediate commercial value as a criterion of success will not often point the way to the discovery of fundamental laws, though these are by far the richest source of ultimate achievement, practical as well as theoretical. Modern electrical engineers do not forget the investigations of Faraday and Hertz in pure sci- 
ence, nor do leading industrial chemists overlook the researches of Gibbs, van't Hoff, and others, which brought them no practical returns, but rendered many modern industries possible. Exclusive attention to industrial research means nothing more or less than the growth of the superstructure at the expense of the foundations. Industrial laboratories are able to offer large salaries and other tempting promises of material advantages, and thus to draw the most promising men from the universities. But while these laboratories should be strongly encouraged, and multiplied to the point where every small manufacturer will realize the value of research methods, this should not be done at the serious expense of pure science. Germany's success on the industrial side is primarily due to her still greater achievements in the university laboratories. The National Academy, by helping to maintain the two phases of American research in stable equilibrium, can perform a service which the truest advocates of applied science will recognize as essential to sound progress.] 
USES OF AN ACADEMY BUILDING

In addition to experimental and illustrated lectures, the Academy might advantageously maintain exhibits freely open to the public, showing the current researches of its members, the most recent European advances in science, and new applications of scientific methods in the industries. It goes without saying that ample space and the best of facilities would be required for this purpose. If carefully worked out, this plan should provide an additional means of keeping the public informed of the progress of research and its bearing on the industries of the country. While emphasis should always be laid in such exhibits on pure science, which it is the Academy's prime object to advance, some of the most striking illustrations of the applications of science should also be introduced.

It is obvious that the Academy can not undertake such activities unless it can obtain a large building of its own. The advantages of having such a building for other purposes have already been touched upon. The attractiveness of the annual meetings would be greatly enhanced if 
they were held in such surroundings as an Academy building could supply. There is a very real difference between the atmosphere of bare halls, casually occupied, and attractively furnished rooms, permanently belonging to the Academy, and charged with the stimulating traditions accumulated during the process of time. The walls should be hung with portraits of past presidents and other eminent men of science, which could easily be obtained if there were a place for them. Moreover, the example of the Royal Society in preserving Newton's telescope and of the Royal Institution in exhibiting the original instruments of Davy, Faraday and other great investigators, should be followed as soon as possible by the National Academy. Doubtless it is still feasible to secure instruments used by Joseph Henry, the two Agassizs, and others who have played a similar part in the history of the Academy. A permanent committee, charged with the collection of portraits, manuscripts, and instruments, and exercising care and diserimination in its selections, would gradually bring together many objects which 
would become more and more valuable with the passage of time. ${ }^{18}$

\section{HISTORICAL EXHIBITS}

[Few writers on civilization in America appreciate how largely the United States has contributed to the development of certain fields of research. The mathematical memoirs of Gibbs were of fundamental importance, while in such fields as celestial mechanics, practical astronomy, astrophysics, experimental physics, geology and paleontology, and in many of the newer phases of biology and experimental medicine, $\mathrm{Na}$ tional Academy members have led the way in a long series of advances. An exhibit of original instruments, manuscripts, and photographs, arranged so as to show the successive contributions of American investigators in various departments of research, would prove an inspiration to many a young and enthusiastic aspirant to the pleasures of original discovery. I shall

18 [A committee of this kind, which was appointed in November, 1913, has already received from Mrs. Henry Draper valuable instruments and original negatives illustrating the pioneer researches in astrophysics of the late Henry Draper.] 
never forget my own delight in first seeing some of Henry Draper's original negatives of stellar spectra. Many of these are now in the possession of the Academy, ready for use in an exhibit of continuous progress in astronomical spectroscopy covering the whole history of the Academy: Rutherfurd's first successful diffraction gratings and large-scale photographs of the solar spectrum; Draper's spectra of stars and planets, the first to show the lines; Young's pioneer observations of the spectra of sunspots and the chromosphere; Langley's bolometric investigations in the invisible region of the infra-red, and his measures of the solar constant of radiation; Pickering's extensive discoveries and classification of stellar spectra photographed with the objective prism; Rowland's invention of the concave grating, and his fundamental studies of solar and laboratory spectra; Michelson's ingenious and varied contributions to the instruments of spectroscopy, comprising the interferometer, echelon and large grating, and his researches with them; Keeler's studies of celestial spectra, inaugurating the era of accurate radial velocity measurements; Campbell's per- 
fection of the stellar spectrograph and the far-reaching results of his years of observation. Each of these American investigators marked a distinct epoch in astrophysical research, and their labors form a continuous chain covering the entire life of their subject. It is still possible to obtain many of their original instruments and earliest photographs, and to exhibit them in an attractive manner. Who would not like to see an actual spectrum formed by Rowland's earliest grating?. A touch of a button operating an are light mounted before the spectroscope slit, is all that would be necessary. And if this can be done in one field of research, there is no reason why similar stimulus can not be given in others, though of course in varying degree. If many subjects can show any such series of advances as we have seen in astronomical spectroscopy, the pessimism shown by some writers regarding American research must surely give way to optimism. And no method of bringing the true state of affairs to easy comprehension, both to men of science and to the public, could equal that of the proposed exhibit. It goes without saying that the ingenious and attractive 
devices of modern museums should be em. ployed, instead of the dry and forbidding exhibition methods of former times.]

The committee on historical apparatus might also have charge of instruments belonging to the various trust funds and no longer in use by the persons to whom the original grants for their purchase were made. In the course of time such a collection would naturally grow to considerable proportions, and the Academy would be enabled to assist its members by the loan of these instruments, as the Royal Society has done so effectively. The objection which is sometimes made to the purchase of standard instruments by the recipients of grants would thus be removed, as such instruments might prove of great service in a collection for general use.

TENTATIVE DESIGN OF AN ACADEMY BUILDING

[The design of an Academy building here reproduced ${ }^{19}$ is intended merely as a

19 [From preliminary sketches by the firm of Shepley, Rutan and Coolidge. Some of the designations of rooms here employed should be modified. The name "conversazione room" for the large public hall comes from the annual conversaziones of the Royal Society, where many instru138 
basis for discussion. The large public hall into which the main entrance leads is for the proposed exhibit of current research, illustrating the latest advances in pure and applied science, both American and foreign. The public would undoubtedly appreciate an opportunity to see under microscopes the most recently discovered bacilli, and to examine specimens illustrating the experimental variation of plants or animals, photographs showing new astronomical discoveries, experimental demonstrations of physical phenomena like the recently found Stark effect (the influence of an electric field on radiation), the structure of crystals, X-ray spectra and their bearing ments and experimental exhibits are shown. The photographic room (not needed on this floor) should be used for council meetings, setting free the room allotted in the plan to the council for a members' ante-room, 'adjoining the meeting room. The meeting, lecture and exhibition halls are shown in Fig. 2 as extending up through the second floor, but the laboratories and other parts of the building would be divided into several stories of ordinary height. The laboratories may of course be devoted to any desired field of research, and the designations are merely intended to suggest that one of these be in the physical and the other in the biological sciences.] 


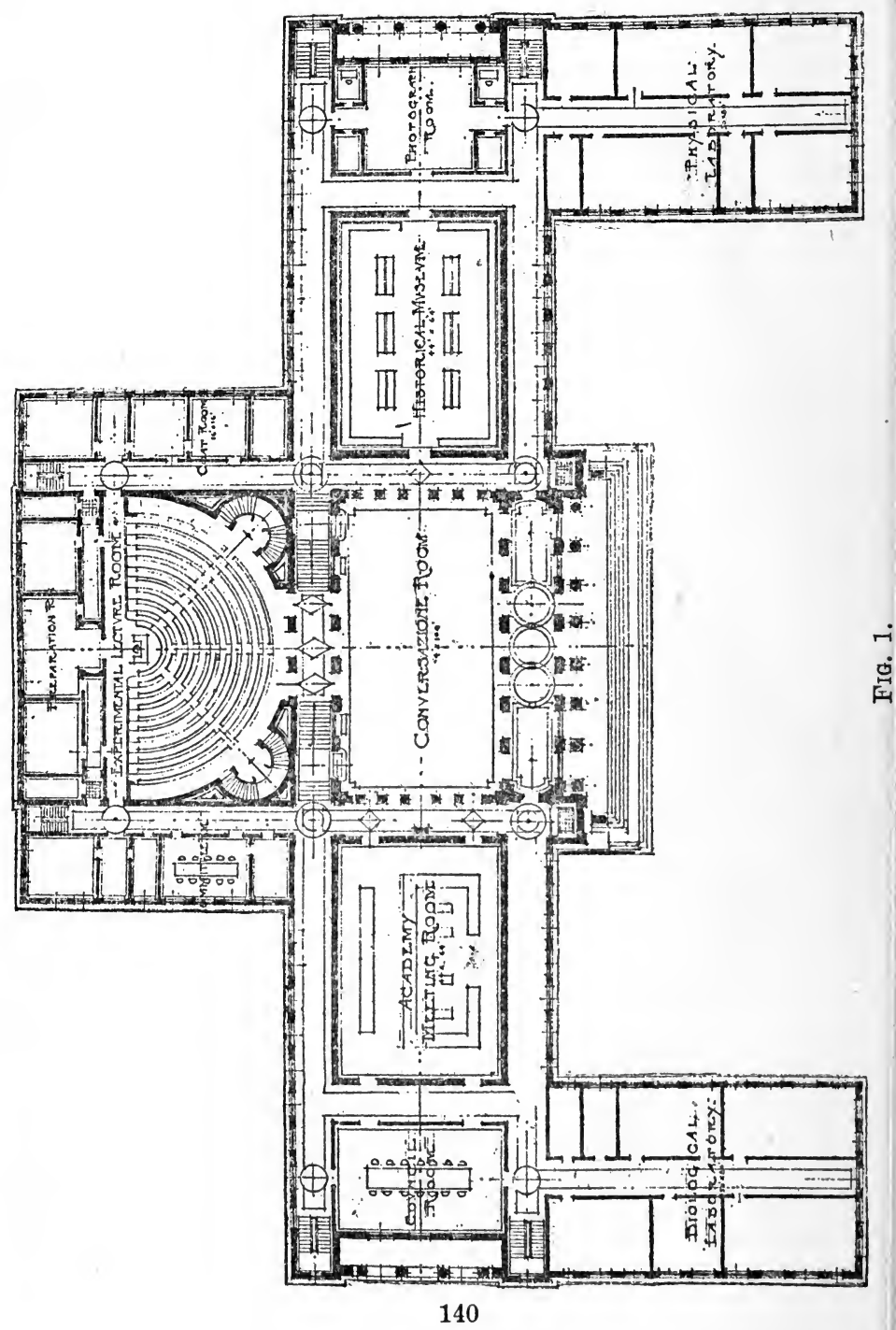


on the constitution of the atom, etc. As the home of such an exhibit, and the place of publication of the Proceedings, announcing the current advances of American research, the Academy would soon be recognized in its true character as the natural center and promoter of the scientific work of the United States.

In the adjoining room to the right the exhibit of historical research would connect the present with the past, and give a clear picture of American progress in the field of science. The possibilities of this exhibit have already been mentioned, but it may be remarked here that one of its prime purposes should be to stimulate further investigation and to aid in the Academy's work of correlating science by indicating converging lines of research. Both of these objects are of course perfectly compatible with the initial idea of commemorating the labors of Academy members.

The lecture hall at the rear of the building completes the group of rooms open to the public. This should embody some of the features which make the lecture hall of the Royal Institution so attractive. The 
provision of ample facilities for experimental demonstrations (including a wellequipped preparation room) which no large lecture hall in Washington contains at present, would add greatly to the means of interesting both men of science and the public.

To the left of the central hall is the Academy meeting room, which might advantageously combine various features found in European academies. One of the most attractive meeting rooms abroad is that of the Paris Academy of Sciences. The provision of a comfortable ante-room, ${ }^{20}$ equipped like a club and providing abundant opportunity for conversation among members, would be a valuable addition. Instead of admitting visitors to the meeting-room they could be better accommodated in a second floor gallery, above the ante-room, similar to the visitors' gallery of the Amsterdam Academy. Finally, a modified seating arrangement (probably retaining the tables for officers and members) would permit the inclusion of a screen and experiment table at one end of the room.

20 In the space here marked "Council Room." 
The main floor would also contain a council room, ${ }^{21}$ and various offices, cloak rooms, serving rooms, apparatus rooms, etc., needed for use in connection with meetings, lectures, exhibits, public receptions and other functions. The offices of the secretaries, editorial rooms, library and reading rooms, private research rooms and other rooms not for public purposes would be on the floors above. The example of the Berlin Academy, ${ }^{22}$ which provides numerous offices (45 in all) in its new building for the compilation of data required for a general catalogue of stars, bodies of Greek and Latin inscriptions, a great Egyptian dictionary, and other similar undertakings, might well be imitated here. For instance, it would have been of great advantage to the Academy if it had been able to furnish Professor Newcomb with offices for the computers employed in his extensive astronomical researches, during the active period which followed his retirement from the Nautical Almanac office.

21 In the space here marked "Photograph Room."

22 See "The Work of European Academies," ScIEnCE, November 14, 1913, p. 692. 
Small study rooms for members staying in Washington, engaged in writing or research involving the use of the Academy library, would also be useful.

The two wings shown to the right and left of the main building are intended for research laboratories. While the great majority of members seem to favor the inclusion of such laboratories in the Academy's scheme of development, there are a few who do not, and it is desirable to point out why they appear desirable. The Academy stands, first and foremost, for research, which it seeks to advance in every effective way. It may thus follow the example of various academies abroad, such as St. Petersburg, which carries on important researches in physics and other subjects; Stockholm, which has long provided in its own laboratories for the spectroscopic inwestigations of Hasselberg; and Berlin, which has produced the extensive investigations already enumerated. Nothing could do more to advance the Academy's influence on the progress of science than the production of important results from its own laboratories. But there is another 
and even stronger argument in favor of their establishment.

It has been well said by one who has studied the problems of the Academy, that the success of its future work must depend upon the discovery of men who are willing and able to devote the necessary time and energy to it. Two Academy members, in commenting on suggestions for a building, remark that not laboratories, but men are needed. Those who are familiar with the history of the Academy are aware of the great amount of unselfish effort which it owes to its officers and members. But the fact remains that a man's first allegiance is to the university or other institution which counts him on its staff. As long as he retains such connections he can devote only his spare time to the work of the Academy, which, nevertheless, demands his best efforts.

The provision of research laboratories, with funds for their maintenance, would enable the Academy to command the entire time and effort of some of the ablest men in the country. The growing work, which already throws heavier burdens than the members realize on the willing shoulders of 
the Home Secretary, may later demand (as in the Royal Society) the services of two men, one representing the mathematical and physical, the other the biological sciences. The only way to secure the undivided service of such men is to offer them adequate salaries, a suitable staff of assistants, and ample laboratory facilities. Thus, while carrying on their researches in the name of the Academy, they would be able to direct the extensive work which the exhibits of current and historical research, the publication of the Proceedings and other contemplated activities must involve. Their position would be much like that of Faraday at the Royal Institution, with added duties defined by the broader range of the Academy's field.

An important object of the proposed research laboratories, therefore, is to attract and hold the men whose unrestricted time and energy the Academy urgently needs. Volunteer service will continue and multiply, but it can never hope to accomplish all that the future will require.

No details of laboratory design need be discussed here. The use of the unit system of rooms, exemplified in the Harvard 
Medical School, would eliminate many difficulties, and facilitate alterations to meet changing needs. A common plant of refrigerating machinery, compression pumps, constant-temperature rooms and other requirements of both laboratories, could be placed on the ground floor of the main building, which would also contain rooms for storing reserve Academy publications and for other miscellaneous purposes.

Enough has been said to indicate some of the possible uses of an Academy building, and the corresponding necessities of the design. The present plan, which is merely tentative, may serve to bring out criticisms and suggestions from members, who will undoubtedly think of many advantageous modifications. A classic treatment is indicated, but this is mainly because of the prevailing conditions in Washington, and the probability that a government site could not be obtained for a building of collegiate Gothic design, for example.

It would be advantageous for the Academy to appoint a strong committee, representing all branches of science, to design a suitable building. I Much time and thought are necessary to secure a satis- 
factory plan, which will provide for present needs, and be readily adaptable to future developments. As for funds, some time may be required to find the sum needed, but the opportunity is such an exceptional one that a willing donor is sure to appear in the future. The only way to obtain gifts for building or endowment is to have a scheme so promising, and plans so attractive as to convince a prospective investor that his funds will be effectively used. Notable cases might be cited where large gifts followed the presentation of effective building designs, which appealed not only to the eye, but equally to the judgment of the donor.]

\section{TRUST FUNDS}

The trust funds of the Academy, as shown in a previous article, have a total of over eighty thousand dollars, the income of which is exclusively devoted to research. In addition, there are other funds totaling over thirty-six thousand dollars, primarily intended for the endowment of medals and prizes, which enjoy a considerable surplus income also available for original investigation. By these means the Academy has 
been able to assist many of the most important researches of American science. A closer connection between the various committees, and the adoption of a concerted plan of action, would perhaps increase still further the usefulness of the funds. As a committee charged with the study of the use of trust funds has admirably expressed it :

The Academy should take the initiative in the organization and conduct of research. It should not wait for applications or for suggestions to come in wholly from the outside. Such suggestions should be urged, but the Academy should not relegate itself to the function of a mere disbursing organization; it should seek rather to determine what projects are worthy of investigation and how the funds may be most judiciously administered.

Such a policy would seem to imply a careful examination on the part of each committee of the existing conditions and needs of research in its own field, and an endeavor, through cooperation with the other committees, to secure a well-balanced and thoroughly effective use of all Academy funds available for investigation. As already suggested, the gradual accumulation of instruments, returned on the com- 
pletion of the work for which they were purchased, should ultimately result in a marked gain in the efficiency of the funds and in the Academy's ability to assist investigators.

[As a body which is rapidly becoming truly representative of the investigators of America, the National Academy is well qualified to act in an advisory capacity to other institutions having funds available for use in research. It frequently happens that trustees of funds thus applicable require such expert advice as, the Academy can give. A parallel case is that of the Royal Society, which selects annually the recipients of the Government Grant Fund of $£ 4,000$.

\section{MEDALS AND PRIZES}

In bestowing the Academy's gold medals for investigations in physics, astronomy, astrophysics, oceanography and the study of meteoric bodies, an attempt should be made, not only to recognize and reward successful investigators, but to do this in accordance with the best interests of future research. A few of the numerous medals awarded by academies, such as the Copley 
Medal of the Royal Society, may be advantageously reserved as a fitting recognition of many years of eminent service to science. But, as Diels ${ }^{23}$ has justly remarked, the majority of medals and prizes will prove of greater value if given to comparatively young men, who still need support and encouragement. By acquaintance with the circumstances under which such men are working, an award may be made at a moment so favorable as to increase its value many fold. Thus recognition by the Academy may supply the precise argument needed to convince university authorities or others in control of research funds of the importance of providing the means necessary to continue and extend the work of the medallist. The same may be said of grants from trust funds. Cases are known in which a comparatively small grant has favorably influenced a board of trustees in deciding to devote large sums to research.

This leads to a consideration of the question of membership in the National Academy. In his valuable discussion of the 23 "Die Kultur der Gegenwart," Teil I., Abteilung I., zweite Auflage, p. 666. 
organization of science, to which reference has already been made, Professor Diels lays great emphasis upon the importance of aiding and encouraging the younger men of science through the award of grants for investigation. That this feeling is general throughout the German academies is shown by the fact that approximately one half of their resources are used for this purpose. Diels also finds cause for congratulation in the fact that the papers of these non-academicians, published in the proceedings, often prove to be the most brilliant of Germany's contributions to science, and at the same time greatly aid in enlivening the work of the Academies. ${ }^{24}$

Nothing could point more clearly to the best field of usefulness of our own $\mathrm{Na}$ tional Academy. As the future of research depends directly upon the younger men, the Academy may properly devote a large share of its efforts to their support and advancement. But moral encouragement is no less important than financial aid. The latter may well be given from the trust funds of the Academy, but the

24 Diels, ibid., p. 665. 
former should not be neglected. The Academy does grant medals, but these are available in only a few fields of research. ${ }^{25}$ Fortunately it also possesses a still more powerful resource in its opportunity to bestow all the advantages and privileges of actual membership.

\section{MEMBERSHIP}

The great European academies differ among themselves in many particulars, most of all as regards membership. At one extreme we find the St. Petersburg Academy, with a president, a director and fifteen members, who are paid good salaries and provided with dwelling houses and laboratory facilities. At the other extreme stands the Royal Society, with 477 members, who receive no salaries or other tangible benefits. The other leading academies, such as Berlin, Paris, Rome and Vienna, lie between these limits. ${ }^{26}$

25 An attempt should be made to secure medals (or preferably money prizes available for the purchase of books or instruments) for mathematics, engineering, chemistry, geology, and the various branches of biology.

26 See "The Work of European Academies," Science, 38, 686 et seq., 1913. 
The large membership of the Royal Society probably reflects, in some degree, the strongly democratic tendencies of England. But the working body of scientific investigators is sufficiently large to prevent the distinction of election to this venerable society from being impaired. In fact, on account of the great pains taken by the Council to inquire into the qualifications of the fifteen Fellows elected annually, the significance of the coveted title of F.R.S. is perhaps even greater to-day than at any earlier period in the history of the Society.

It can hardly be doubted that investigators of real ability are quite as numerous in the United States as in England. The available statistics indeed indicate that a much greater number of men are engaged here in research. The conditions are thus very different from those existing in 1863, when the National Academy was founded, with 50 members as its limiting number. Since 1906, when the maximum number of members elected annually was increased from five to ten, there has been a very perceptible change in the spirit of the Academy. By taking in a larger proportion of the younger men actively engaged in re- 
search, the Academy has increased its contact with living issues, and made itself more truly representative of American science. For the present, the election of ten new members annually may suffice, but I believe that the time will soon come when the limit should be raised from ten to fifteen.

It can not be gainsaid that a large number of able American investigators, who in England would certainly be elected to membership in the Royal Society, are still outside of our National Academy. The reason for this lies partly in the limit imposed on membership, and partly in the method of nomination, which seems to me susceptible of improvement. One difficulty, which will certainly increase in the future, has come about through the development of new fields of research. A man classed as a mathematician or an astronomer, both of which subjects are well represented in the Academy, is sure to receive consideration when nominations are being made. But if his subject be a comparatively new one, not represented among the nominating sections included in the existing classification of the Academy, his claims to recognition will be much less likely to command due attention. 
The constitution provides that the Council may nominate new members, but this privilege is exercised only in rare cases, and in any event there are certain disadvantages in this procedure. II trust that some means can be found of improving the system of nominations so as to overcome this difficulty, which now deprives the Academy of valuable members. ${ }^{27}$

As for the qualifications of membership, it can hardly be doubted that the original plan of basing selections solely on the original contributions to science of the candidates should always be maintained. While it is true that eminent administrators and others who exercise large influence in the intellectual world might prove to be of great service as members of the Academy, a wide departure from this fundamental principle would soon detract from the standing of the Academy as the national representative of original research. Thus while eminent services to the public should by no means be excluded from the field of the Academy's interests, and may well be recognized by the award of special medals founded for this purpose, actual member-

${ }^{27}$ [A committee is now at work on this subject.] 
ship should be confined to original investigators.

\section{SCOPE OF THE ACADEMY}

Here we may inquire as to the true scope of the Academy's work. In what degree should it confine its choice of members to the physical and natural sciences, and in what measure may it recognize successful research in such fields as philosophy, archeology, political economy, and history? The answer to this question will depend in part upon one's opinion of the chief object of the Academy. There are those who feel that the most important function of the National Academy is to confer distinction by election to membership. If this were its prime object, the participation of the members in the work of the Academy would be a minor matter, and any one of sufficient reputation as an investigator might be chosen. But if we agree, as I think the large majority will, that the Academy should be looked upon as a working body, and that its privilege of conferring distinction by election to membership is only one of many important functions, it seems to me that a means of defining our choice 
of investigators in the humanities may easily be found.

A single philologist, or a single political economist, may find but little of interest to himself in the proceedings of a body made up almost exclusively of representatives of the physical and natural sciences. If so, he may not attend the meetings, and his membership would then serve merely as a mark of distinction. Deferring for a moment the discussion of the broad question whether the Academy should ever be reorganized in two or more large classes, after the manner of the Berlin Academy, it seems to me that we should augment the value of election by furnishing real reason to every member for participation in the work of the Academy. For example, in its committee on anthropology and psychology the National Academy now has three members engaged in the study of archeological problems. Although their work relates primarily to American ethnology, it differs in no essential respect from that of the classical archeologist or the student of Egyptology or Assyriology. Would it not be advisable, therefore, when the Academy chooses its next member from outside the 
domain of the physical and natural sciences, to elect an archeologist from one of these fields? If this were done he might be expected to take a more active interest in the work of the Academy, which would benefit by his contributions to its proceedings. ${ }^{28}$

The advantages which might result from a wider extension of the scope of the $\mathrm{Na}$ tional Academy raise the question whether an organization resembling that of the Berlin Academy will ever become desirable. This problem was long and seriously discussed by the Royal Society, and the negative decision of its deliberations led to the establishment of the British Academy. In spite of this decision, some of its leading Fellows still believe that the Royal Society should have made room for a larger body of philosophers, historians and philologists than it now contains. Both the Royal Society and the National Academy have wisely refused to limit their membership

28 William Dwight Whitney and William James resigned from the Academy, probably because they were the sole representatives of their subjects. 
to the physical and natural sciences. Such historians as Bryce and Morley and such Egyptologists as Petrie are now counted among the Fellows of the Royal Society, and Weld states that 116 archeological papers were published in the Philosophical Transactions before $1848 .^{29}$ But the large proportion of Fellows concerned with the physical and natural sciences, and the failure of the Society to recognize the philosophical-historical group in its organization, has prevented the Royal Society from taking part in the Section of Letters of the International Association of Academies, where the British Academy now represents England.

The National Academy, as a member of the Section of Science of the International Association, is in a position to secure adequate representation in foreign affairs of American interests in the natural sciences. The United States are also entitled to representation in the Section of Letters, but the present organization of the National Academy and the absence of a national 29 "History of the Royal Society," Vol. 2, p. 565 . 
body similar to the British Academy, ${ }^{30}$ still leaves a vacancy there.

In my opinion it would not be advisable, under present conditions, to reorganize the National Academy on the model of the Berlin Academy. But I am heartily in sympathy with the idea of widening its scope and its field of interests, in some such way as that indicated above. This plan would permit the Academy to honor able investigators outside of the physical and natural sciences, and at the same time gradually to build up small groups of these members who would aid the Academy in the development of its work. Ultimately the Academy might extend this phase of its activities sufficiently to secure representation in the Section of Letters of the International Association of Academies.

\section{LOCAL ACADEMIES}

A subject to which I have devoted special attention in the study of the problems of the National Academy, is its relationship to the various local academies which are widely distributed over the United

so The National Institute of Arts and Letters occupies a different field. 
States. These societies are of the greatest importance in the further development of American research, and the cultivation of an intelligent interest in the problems of science. Some of them have grown to such large proportions and established such excellent organizations that they need no assistance or encouragement from the $\mathrm{Na}$ tional Academy. But after these exceptional societies have been excluded, there remain a great number of others, which the National Academy ought to be in a position to assist in various ways.

In an early period of its history, the Paris Academy of Sciences established close official relations with certain provincial academies in various parts of France. In fact, the Society of Montpellier is described in its royal letters patent as "an extension and a part" of the Paris Academy of Sciences. ${ }^{31}$ But a general plan of federation between the provincial academies and the Institute of France, such as that described by Bouillier in the work just cited, has never been carried into effect, and the old official relations have been discontinued.

31 Bouillier, "L'Institut et les Académies de Province," p. 70. 
After careful consideration of Bouillier's plan, I doubt whether it could be advantageously applied in the United States under existing conditions.

This conclusion, however, does not mean that the National Academy can not be of service to local organizations. I believe, on the contrary, that it might find many ways and means of aiding them. The prime object is to secure a high standard of accomplishment among the minor academies remote from the chief centers of research, and to give the encouragement which the production of good work under unfavorable conditions so richly deserves. It should be possible to discover methods of realizing these ends, and thus to contribute to the strength and standing of the local academies and the progress of American research.

[It will be noticed that comparatively little attention has been given in this paper to the relationship of the Academy to the national government. This is due to no underestimate of the importance of the connection, but rather to the strong desire that this chief implication of the Academy's charter should ultimately be realized 
in the fullest sense. Valuable suggestions for cooperation with various departments of the government have been made by Academy members, and every effort should be exerted to carry them into effect. But recent experience indicates that the most promising way to accomplish this lies in first developing the standing and prestige of the Academy. When it becomes more widely and favorably known for its contributions to scientific progress, and is universally recognized as the national and authoritative representative of American science, the Academy's influence with Congress and with the various officers of the government will be far more potent than at present. I therefore believe that no effort should be made to press a demand for greater governmental recognition until the publication of the Proceedings and other new activities have had time to produce their anticipated effect.]

In summarizing the suggestions offered in this paper, we see that many of the new activities proposed for the National Academy can not be undertaken without a suitable building. If this can be obtained, 
and adequately endowed, the Academy will be able greatly to extend its influence and usefulness both at home and abroad, through original researches, increased service to members, public lectures and exhibits, and greater cooperation in international projects. Under present conditions, the International Association of Academies could hardly be invited to meet in Washington. But if established in a home of its own, the Academy might ultimately succeed the Royal Society and the Academies of Paris, Rome, St. Petersburg and Berlin as the leading Academy of the Association for a period of three years. In this position it could contribute in a more effective way to the furtherance of international science, and to the study of the great problems of cooperative research, which offer large possibilities of extension and development. ${ }^{32}$

The one way to secure a building and endowment is to prove by continual increase of efficiency that the Academy can use them to advantage. The establishment of Proceedings, the institution of lecture courses,

$32 \mathrm{I}$ hope to discuss the international relations of the Academy in a future article. 
the encouragement of broader methods of science teaching, and closer identification with the general interests of science as represented in all movements for the promotion of research and the diffusion of scientific knowledge, are opportunities open to immediate realization, and deserving of the most careful consideration by the Academy.

MOUNT WILsON

SOLAR OBSERVATORY 







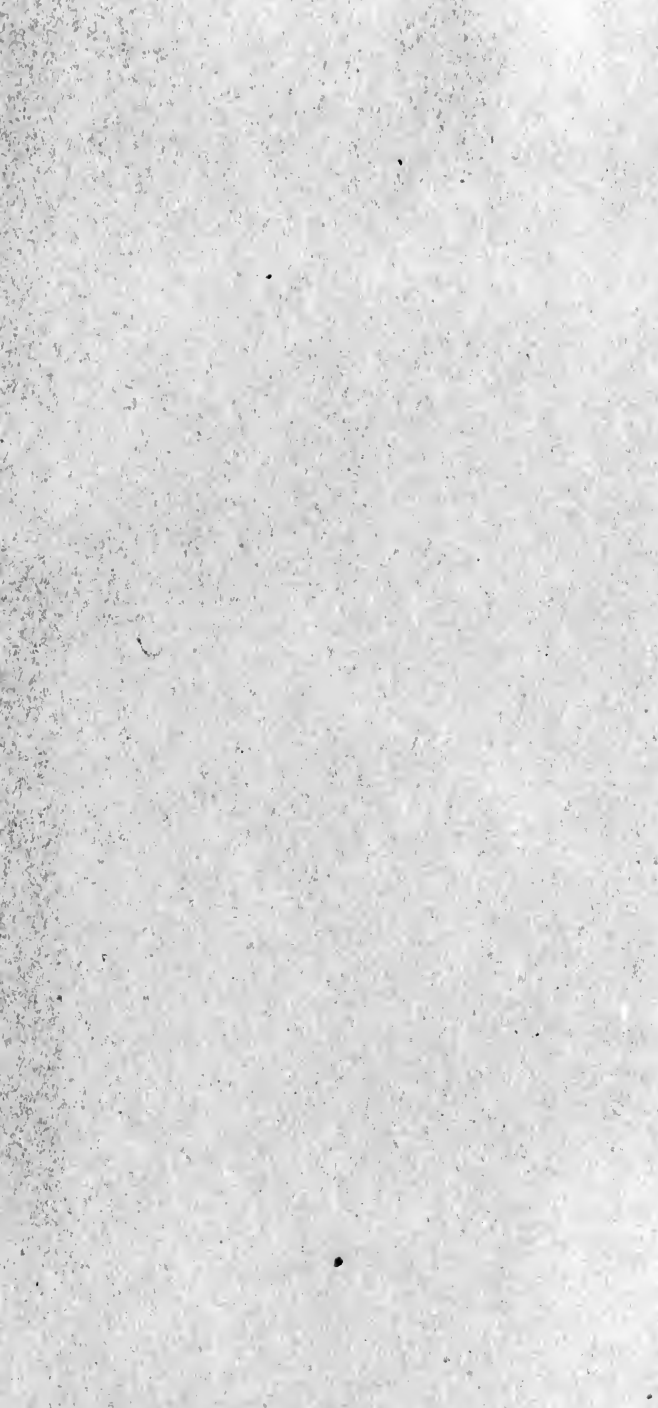


RETURN TO the circulation desk of any

University of California Library

or to the

NORTHERN REGIONAL LIBRARY FACILITY

BIdg. 400, Richmond Field Station

University of California

Richmond, CA 94804-4698

$\overline{4}$

ALL BOOKS MAY BE RECALLED AFTER 7 DAYS

- 2-month loans may be renewed by calling

(415) 642-6753

1-year loans may be recharged by bringing books to NRLF

- Renewals and recharges may be made 4 days prior to due date

DUE AS STAMPED BELOW

\section{DEC.12.1991}

DEC 141990

Santa Cruz sitper

verurinea o,

NOV 191991

'via Cnar Jitne.

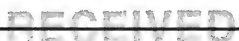

JUN 081995 


\section{GENERAL LIBRARY - U.C. BERKELEY

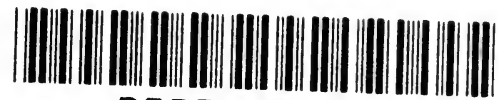 B000720252}

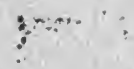

\section{Vi206241 .}

$$
\begin{aligned}
& \text { ASS } \\
& 425
\end{aligned}
$$

THE UNIVERSITY OF CALIFORNIA LIBRARY 
